\title{
EFEITOS DE DIFERENTES SEQUÊNCIAS DE CULTURAS EM LATOSSOLO VERMELHO-AMARELO DO VALE DO PARAIBA (SP).
}

\author{
JOSÉ DAMIÃO DE JESUS FILHO \\ Engenheiro Agrônomo
}

Orientador: Prof.Dr. JORGE DE CASTRO KIEHL

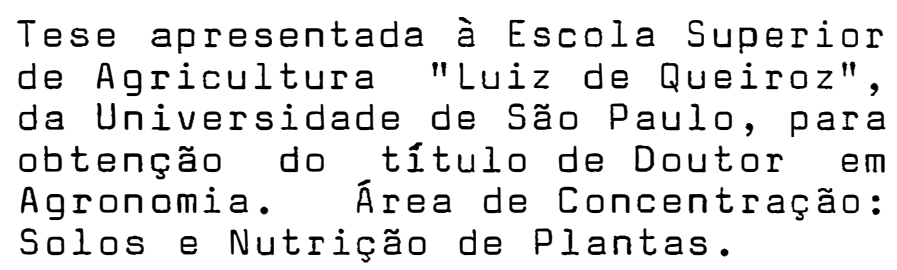

PIRACICABA

Estado de São Paulo - Brasil

Agosto de 1992 
Ficha catalografica preparada pelá Seça de Divisao de Eiblioteca e Documentaçă -

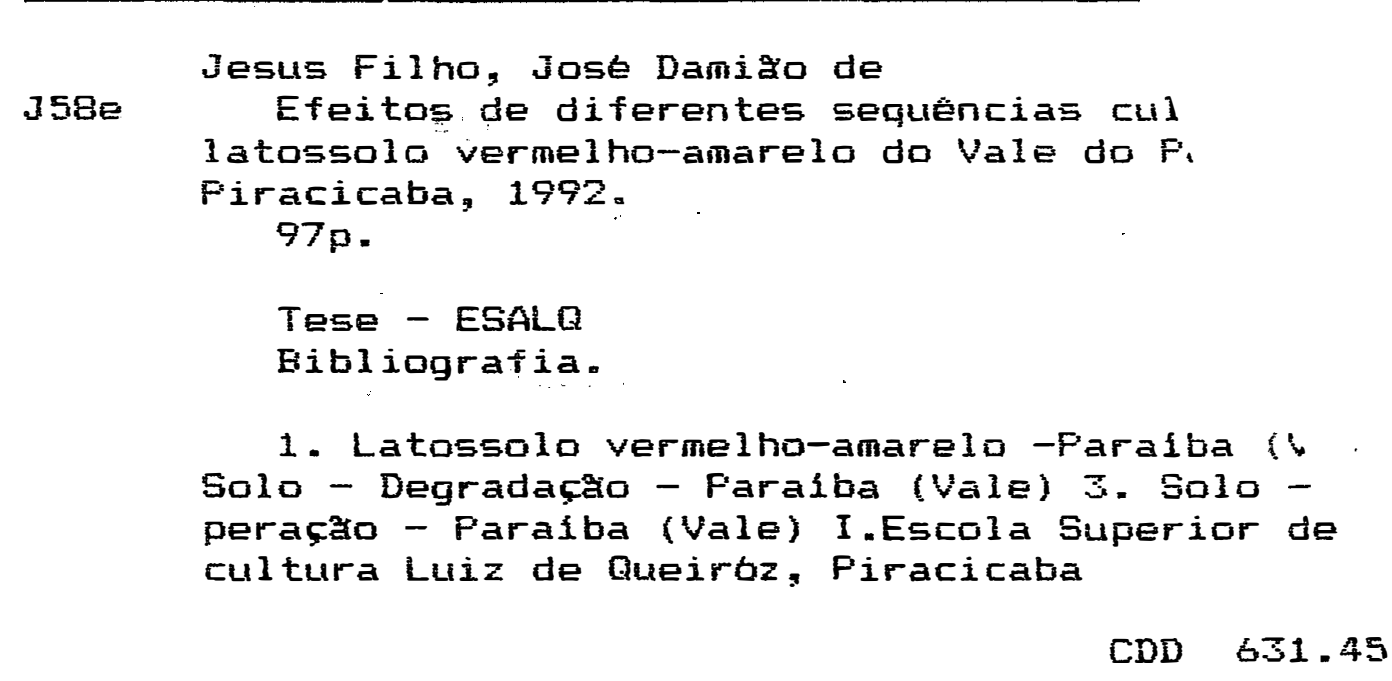




\section{EFEITOS DE DifERENTES SEQUÊNCIAS DE CULTURAS EM LATOSSOLO VERMELHO-AMARELO DO VALE DO PARAIBA (SP).}
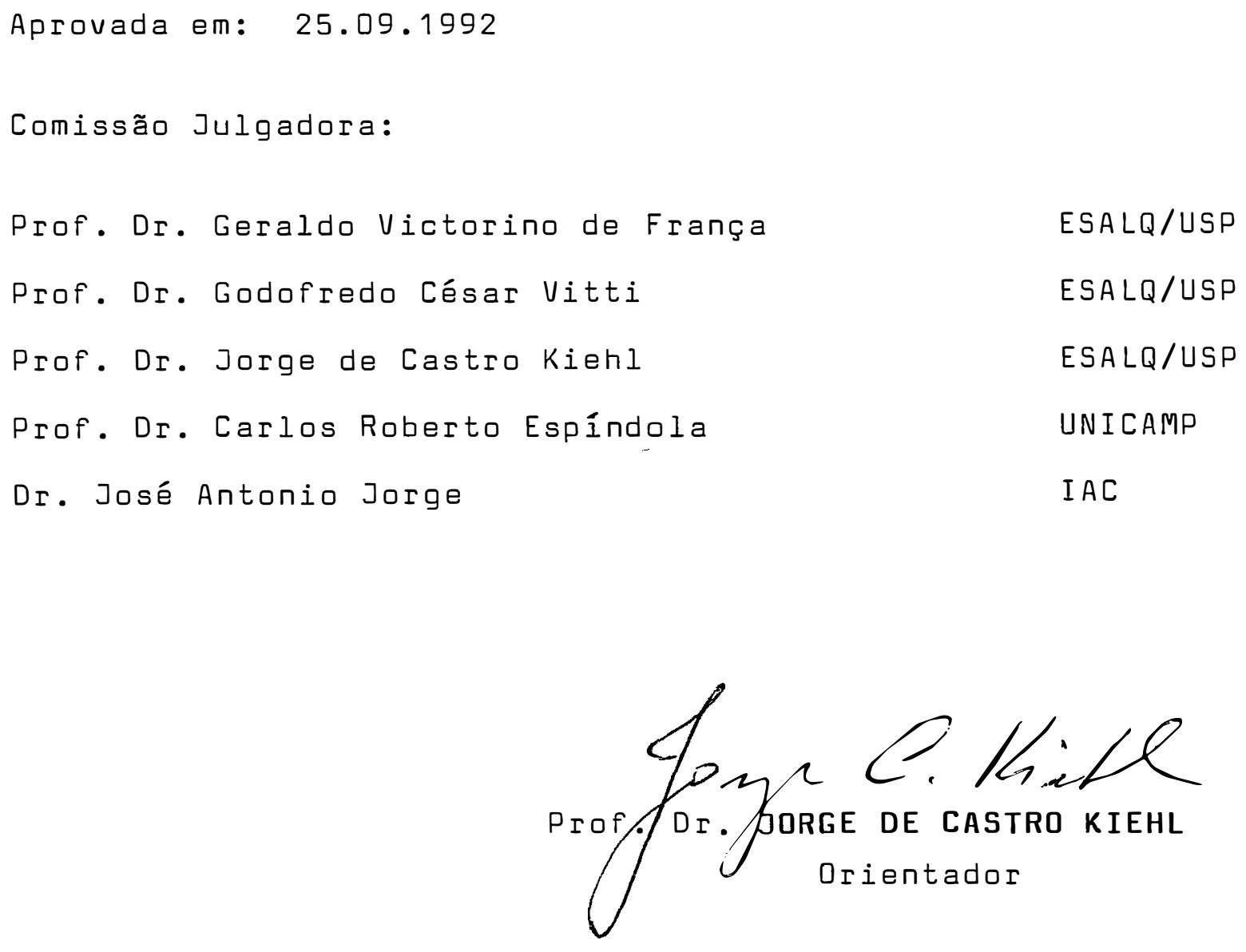
i.

A BRUNA, minha querida filha com amor. 
AGRADECIMENTOS

À Escola Superior de Agricultura "Luiz de Queiroz", pelo acolhimento e pela oportunidade de realizar o curso.

Ao Conselho Nacional de Desenvolvimento Científico e Tecnológico (CNPq) pelo apoio financeiro na execução. da pesquisa.

À CAPES/PICD, pela concessão da Bolsa de Estudo.

À Universidade de Taubaté (UNITAU), pelo apoio financeiro, incentivo, confiança, solidariedade e apreço, durante o desenvolvimento do curso.

Ao Prof. Dr. Jorge de Castro Kiehl, pela eficiente orientação, apoio, compreensão, amizade e estímulo no decorrer do curso.

Ao Dr. José Antonio Jorge, do Instituto Agronômico de Campinas (IAC), pela orientação e sugestões durante o desenvolver da pesquisa.

Aos Laboratoristas do Departamento de Ciências Agrárias da UNITAU, Eng@ Agr@ João L. Gadioli, Fernando e Rose, pelos serviços prestados e amizade.

Aos Funcionários da Fazenda Piloto do Departamento de Ciências Agrárias, em particular o Engo Agrônomo Paulo, Geraldo, Nelson e José Augusto, pela coope ração e solidariedade nos trabalhos de campo.

Aos Graduandos e Graduados do Departamento de Ciências Agrárias, pela ajuda na execução da pesquisa nos níveis de campo e laboratório. 
LISTA DE TABELAS $\ldots \ldots \ldots \ldots \ldots \ldots \ldots \ldots \ldots \ldots \ldots \ldots \ldots \ldots$

1. INTRODUÇ̃̃o $\ldots \ldots \ldots \ldots \ldots \ldots \ldots \ldots \ldots \ldots \ldots \ldots \ldots \ldots$

2. Revisão de literatura $\ldots \ldots \ldots \ldots \ldots \ldots \ldots \ldots$

2.1. Efeito do preparo do solo sobre as propriedades físicas ................. 4

2.2. Recuperação de solos degradados ........ 10 2.2.1. Efeito da matéria orgânica e da cobertura vegetal ........... 10

2.2.2. Efeito da rotação de culturas ...

2.2.3. Efeito de práticas conservacionistas .....................

2.2.4. Efeito da adubação e da calagem na agregação do solo ...........

3. MATERIAL E MÉTODOS ................... 30

3.1. Área experimental ............... 30

3.1.1. Localização .............. 30

3.2.2. Clima regional ............. 30

3.1 .3 . Solo $\ldots \ldots \ldots \ldots \ldots \ldots \ldots \ldots \ldots \ldots, 31$

3.2. Experimento .................. 31

3.3. Métodos de análise ............... 36 
3.3.1. Análises físicas .............

3.3.1.1. Distribuição do tamanho dos agregados estáveis em água ...............

3.3.1.2. Macro e microporosidade, e porosidade total .....

3.3.1.3. Densidade do solo e de partículas ...........

3.3.1.4. Análise granulométrica.

3.3.1.5. Umidade de campo .......

3.4. Análises químicas .................. 38

4. RESUltados E DiscUSSÃO ................... 41

4.1. Efeito de culturas sucessivas sobre as características químicas .............

4.1.1. Matéria orgânica .............

4.1.2. Potássio trocável .............

4.1.3. P-extraído (P-resina) ..........

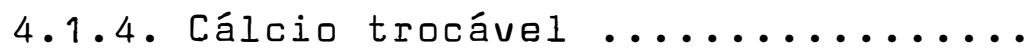

4.1.5. Magnésio trocável ...........

4.1.6. $\mathrm{pH}$ em $\mathrm{H}_{2} \mathrm{O}$ e em $\mathrm{CaCl}_{2} \ldots \ldots \ldots \ldots$

60

4.1.7. Acidez potencial $(H+A l)$ e alumí nio trocável (Al) ............

4.2. Efeito das seqüências culturais sobre as

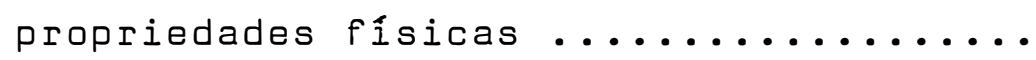


4.2.1. Efeito das seqüências culturais na estabilidade de agregados es-

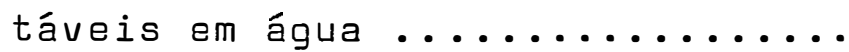

4.2.2. Efeito das seqüenncias culturais na densidade e porosidade do solo 


\section{LISTA DE TABELAS}

Página

1 - Seqüências culturais estudadas desde agosto/87

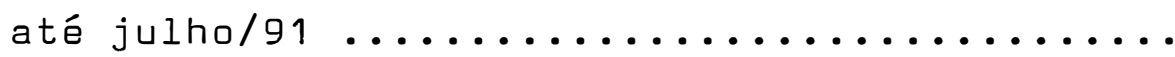

2 - Propriedades físicas e químicas de um Latossolo Vermelho-Amarelo em duas profundidades, antes da implantação do experimento (setem -

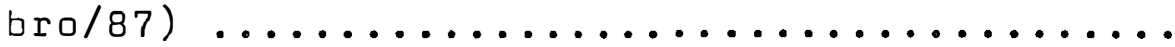

3 - Porcentagem de Matéria Orgânica no solo,durante a condução das diferentes seqüências cultu-

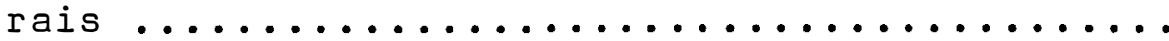

4 - Potássio trocável obtido durante a condução das diferentes seqüências culturais ............

5 - Fósforo extraido (P-resina) obtido durante a condução das diferentes seqüências culturais..

6 - Cálcio trocável do solo determinado nas dife-

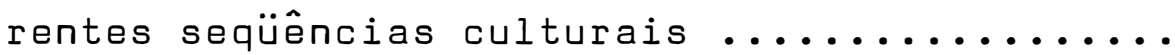

7 - Magnésio trocável do solo determinado durante a duração das seqüências culturais ..........

8 - $\mathrm{pH}$ em $\mathrm{H}_{2} \mathrm{O}$ determinado durante a condução das diferentes seqüências culturais ............

9 - $\mathrm{pH}$ em $\mathrm{CaCl}_{2}$, determinado durante a condução das diferentes seqüencias culturais ........... 
vii.

Página

10 - $H+A l$ (acidez potencial) determinado durante a condução das diferentes seqüências culturais.

11 - Alumínio trocável determinado durante a condução das diferentes seqüenncias culturais ...

12 - Efeito da seqüencia de culturas na estabili dade de agregados estáveis em água .........

13 - Efeito da seqüência de culturas na densidade e porosidade do solo na profundidade de 0-20

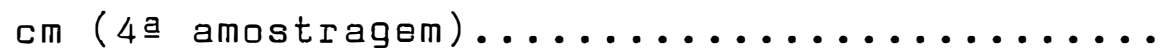

14 - Efeito da seqüência de culturas na densidade e porosidade do solo, na profundidade de 20-

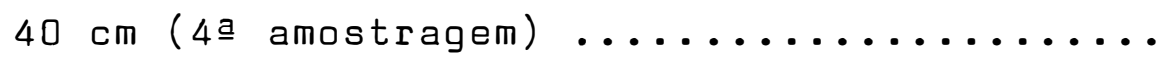




\title{
EFEITOS DE DIFERENTES SEQUENEIAS DE CULTURAS EM LATOSSOLO VERMELHO-AMARELO DO VALE DO PARAIBA (SP).
}

\author{
Autor: José dAMIÃO JESUS FILHO \\ Orientador: Prof.Dr. JORGE DE CASTRO KIEHL
}

RESUMO

Para estudar o efeito de diferentes sequências culturais na recuperação de um Latossolo Vermelho-Amarelo (textura média/argilosa) na região do Vale do Paraíba (Taubaté-SP), foi conduzido um experimento de campo na Fazenda Piloto do Departamento de Ciências Agrárias da Universidade de Taubaté (UNITAU), com o qual se acompanhou,por meio de três amostragens, a evolução das propriedades físicas e químicas durante quatro anos sucessivos (verão/87 a verão/91). As propriedades físicas determinadas foram: estabilidade de agregados em água (diâmetro médio ponderado DMP); porosidade e densidade do solo. Realizaram-se também, as seguintes avaliações químicas: matéria orgânica; cátions trocáveis (cálcio, magnésio, potássio e alumínio); hidrogênio+alumínio trocáveis; fósforo extraído (P-resina); pH em $\mathrm{H}_{2} \mathrm{O}$ e em $\mathrm{CaCl}_{2} \cdot$ 
Após a análise e interpretação dos resultados constatou-se um efeito significativo das seqüencias cultuna recuperação das propriedades físicas e químicas do Latossolo Vermelho-Amarelo, na profundidade de 0-20 e 20-40 cm. O diâmetro médio ponderado (DMP) foi a propriedade física mais beneficiada pelas seqüencias culturais estudadas. Observou-se, também, redução na densidade do solo na profundidade de 20-40 cm, contudo, não se denotaram diferenças significativas entre as diferentes seqüencias estudadas. De uma forma geral, verificou-se maior efeito das seqüencias culturais sobre as propriedades físicas e químicas do solo na profundidade de 0-20 cm do que na de $20-40 \mathrm{~cm}$. 


\title{
EFFECTS OF DIFFERENTS CROPS SEQUENCES IN RED-YELLOW OF PARAIBA VALLEY.
}

\author{
Author: JOSÉ DAMIÃO DE JESUS FILHO \\ Adviser: Prof.Dr. JORGE DE CASTRO KIEHL
}

\section{SUMMARY}

The effect of ten different crop sequences on the recuperation of a Red-Yellow Latosol of Paraiba Valley, State of São Paulo, Brazil, was studied by means of physical and chemical analysis performed in soil samples collected from the depths of $0-20 \mathrm{~cm}$ and $20-40 \mathrm{~cm}$. The samples were collected in three different times during four sucessive cropping years (from Summer of 87 to Summer of 91), and the following analysis were performed: aggregate stability in water or mean weight diameter (M.W.D.); porosity; bulk density; organic matter content; exchangeable cations (calcium, magnesium, potassium and aluminum); potential acidity $(H+A l)$; resin-extractable phosphorus; and $\mathrm{pH}$ in water and in $0.01 \mathrm{M} \mathrm{CaCl}_{2}$ suspensions.

A significativa effect of the crop sequences on both physical and chemical properties of the Red-yellow was observed. The M.U.D. was the most improved soil property by the crop rotations. Lower soil bulk density at the depth 
xi .

of 20-40 cm was also observed. In general, the effect of the crop sequences on the physical and chemical properties of the Red-Yellow Latosol was more pronounced in the $0-20 \mathrm{~cm}$ than in the $20-40 \mathrm{~cm}$ layer. 


\section{INTRODUÇÃO}

Nas regiões tropicais e subtropicais em que - Brasil está inserido e, mais especificamente, na região do Vale do Paraíba, geralmente encontram-se solos em estágio acelerado de degradação. Este fato é explicado pelo uso intensivo de implementos agrícolas, elevadas temperaturas, altas precipitações pluviométricas, lixiviação e erosão intensas, além da rápida oxidação da matéria orgânica.

Apesar de existirem poucas informações científicas sobre as atuais condições dos solos da região do Vale do Paraíba, observa-se que grande parte deles revela grandes riscos de erosão e baixas produções. A degradação de sua estrutura e a compactação subsuperficial é decorIente do manejo inadequado, o qual, na maioria das vezes, caracteriza-se pela mobilização intensiva do solo, associada à incorporação ou queima dos restos culturais e plantio morro abaixo em áreas declivosas. Essas consequências, em conjunto com as chuvas de verão de alta intensidade, levam a um maior escoamento superficial e carreamento de partículas de solo, de matéria orgânica e de nutrientes, refletindo na queda de produtividade. 
- Latossolo Vermelho-Amarelo (textura médial

argilosa) é uma classe taxonômica representativa da região do Vale do Paraíba, havendo necessidade de informações mais detalhadas sobre ele para que se possa delinear um manejo mais adequado e mais técnica e economicamente viável. De qualquer forma, as práticas de calagem e adubação melhoram as condições químicas: porém, seus efeitos sobre as características físicas e biológicas, isoladas ou combinadas com vegetação viva ou morta, sobre diferentes sistemas de uso e manejo, não são bem conhecidos.

Neste sentido, após o declínio da cultura do café, como também de outras de interesse econômico para a região, torna-se fundamental desenvolver pesquisas que indiquem as melhores técnicas de uso e manejo para os solos do Vale do Paraíba.

0 presente estudo teve como objetivo avaliar - efeito de diferentes seqüências culturais na recuperação de um Latossolo Vermelho-Amarelo degradado, na região do Vale do Paraíba/SP. 


\section{REVISÃO DE LITERATURA}

Desde os estádios iniciais do processo de formação dos solos, estabelece-se um equilíbrio ecológico dinâmico entre o solo, o clima e a vegetação nativa.o ideal seria que este ambiente não fosse perturbado; entretanto, a necessidade da utilização agrícola do solo, visando à obtenção de fibras, alimentos, óleos, resinas, e outros produtos, pode perturbar o equilíbrio existente. Segundo CASSOL (1984), o uso agrícola adequado dos solos deve ter por objetivo a menor perturbação do equilíbrio existente, através da manutenção ou melhoria das características naturais dos solos, de maneira que a capacidade produtiva do mesmo seja mantida ou melhorada por longo tempo.

No sistema de produção agrícola, o manejo do solo consiste num conjunto de operações efetuadas no próprio solo com o objetivo de propiciar condições favoráveis à semeadura, germinação e desenvolvimento das culturas. Tais operações envolvem, de maneira geral, trabalhos de preparo do solo, calagem, plantio e fertilização, controle de plantas daninhas e tratos culturais, bem como aproveitamento de residuos culturais. Portanto, no manejo do solo, uma das práticas mais importantes é o seu preparo. 
0 preparo do solo, quando efetuado intensivamente e em condições de umidade acima da ideal, traz sérias conseqüências, pois leva à degradação da estrutura tanto nas camadas superficiais quanto nas subsuperficiais, comprometendo a produtividade. Na ocorrência de chuvas intensas, a influência imediata se dá sobre a taxa de infiltração e sobre o escoamente superficial, agravando, dessa forma, as perdas de solo e água.

\subsection{Efeito do preparo do solo sobre as propriedades fí- sicas}

Segundo DERPSCH (1983), as técnicas de preparo do solo desenvolvidas na Europa, sob clima temperado, em topografia pouco acidentada e com chuvas caracterizadas por uma energia cinética baixa, foram inicialmente introduzidas, sem modificações nas regiões tropicais. Essas técnicas, que consistem no enterrio de todos os resíduos vegetais, deixando a superfície do solo desprotegida, mostram, sob condições de altas temperaturas e de chuvas intensas com alta energia e em relevo acidentado, efeitos prejudicias ao solo. Estes efeitos se tornam mais graves com a motomecanização, agravada pelo uso de máquinas e implementos agríco las cada vez mais pesados e através do cultivo intensivo (preparo bianual) da terra; o resultado é o aumento da pressão exercida pelo tráfego contínuo de máquinas e implemen tos, ocasionando a compactação do solo, principalmente quan- 
do o terreno for cultivado com um teor de umidade acima da média.

A mudança na estrutura original do solo, motivada pelos processos pedogenéticos ou decorrentes do manejo inadequado, pode provocarum aumento ou diminuição do volume de poros, o que se reflete na densidade do solo. 0 aumento na densidade do solo promove o adensamento ou a compactação do mesmo. A compactação devida aos processos pedogenéticos é chamada de "camadas adensadas", reservando - termo "camada compactada" para aquelas em que sua compactação é devida ao manejo do solo.

Segundo CAMARGO (1983), o rearranjamento de partículas primárias e agregados, ocasionados pelas máqui nas e implementos agrícolas, pode ser considerado a maior causa da compactação. Reduções nos teores de matéria orgâ nica no solo também podem provocar a compactação. Conforme cita BAVER (1965), a matéria orgânica estimula a formação de grandes agregados estáveis, conferindo ao solo maior porosidade, total e, por conseguinte, menor densidade e maior condutividade hidráulica, assim como maior taxa de difusão de óxigênio.

A densidade do solo é um parâmetro muito utilizado para indicar a ocor̀rência de compactação nos solos, devendo ser relacionado com a textura e a densidade de partículas para a sua correta interpretação (BALLESTERO, 
1984). Segundo JORGE (1983), a compactação do solo determina as relações entre ar, água e temperatura, as quais influenciam a germinação, a emergência das plântulas, o crescimento radicular e praticamente todas as faces do desenvolvimento vegetal.

- O preparo convencional, tal como praticado na maior parte da Região Sudeste do Brasil, envolve a lavia e gradagens, com os restos culturais na maior parte das vezes sendo previamente queimados ou incorporados ao solo, que se torna pulverizado superficialmente e mais exposto à ação dos agentes erosivos. Quando da incidência de chuvas, for ma-se selo (DULEY, 1939), que diminui a circulação de água e ar no perfil do solo.

As condições físicas do solo são influenciadas pela intensidade de preparo, tipos de equipamentos empregados, profundidade de corte do implemento, resistência dos agregados, densidade e natureza dos componentes do solo, assim como pelas condições neles prevalecentes, como por exemplo, a umidade.

o uso intensivo de implementos agrícolas,juntamente com o tráfego excessivo de máquinas pesadas, prin cipalmente quando empregados em condições inadequadas de umidade, provocam a degradação da estrutura do solo.os discos, ao trabalharem no solo, causam espelhamento subsuper ficial que sela os poros, enquanto o peso das máquinas cau- 
sa degradação, compactando o solo abaixo da camada revol vida. Conseqüentemente, ocorre o aumento da densidade do solo e da resistência à penetração das raízes, como também redução da capacidade de infiltração de água.

A essa camada compactada dá-se o nome de piso-de-arado ou piso-de-grade. Em conseqüência, qundo ocorrem chuvas de alta ou baixa intensidade, porém freqüentes,a camada superficial preparada satura-se rapidamente, ocorrendo escoamento superficial e arraste de partículas de solo e de defensivos agrícolas. O resultado é a poluição e o assoreamento de rios e açudes, o que aumenta a incidência de enchentes e causa sérias conseqüências sociais.

LAL (1974) constatou diferenças acentuadas na estruturação, ao comparar a infiltração acumulada em um solo franco-arenoso sob floresta, com a do mesmo solo, cultivado um ano com milho ou deixado sem cobertura vegetal durante o mesmo período. Na área cultivada houve uma redução de 40\% na infiltração acumulada e, na área descoberta, de $73 \%$, enquanto na área com floresta, a infiltração acumulada foi de $100 \%$.

MACHADO (1976), CINTRA et alii (1983) e

SILVA (1980) constataram que os solos cultivados apresentam uma acentuada degradação de suas propriedades físicas em relação ao seu estado inicial. Segundo esses autores, os solos cultivados, comparados aos não cultivados, caracteri- 
zam-se por apresentar maior proporção de microporos e valores mais elevados de densidade, sendo mais baixos os de matéria orgânica, macroporos, porosidade total, macroagrega dos e na infiltração acumulada.

DALLA ROSA (1981) menciona que em solos degradados um aumento no teor de matéria orgânica e uma recuperação da estrutura podem ser conseguidos através de um manejo com menor mobilização e adoção de um sistema de rotação de culturas com aproveitamento dos restos culturais.0 efeito adverso do preparo convencional inadequado na estrutura do solo é bem evidenciado pela oxidação da matéria orgânica, devido a sua exposição na superfície e por reduzir a cobertura residual; por consegüinte, o solo torna-se mais susceptível à ação das gotas de chuva.

FERNANDES et alii (1983), OLIVEIRA et alii (1983) e CINTRA (1983) verificaram os efeitos prejudiciais da intensidade acentuada do preparo do solo no grau de pulverização dos agregados, tormando-os facilmente transportáveis pelo escoamento superficial; observaram, também, decréscimo na porosidade e aumento na densidade do solo, ocasionando uma redução na taxa de infiltração de água. Além dessas conseqüências, com a compactação do solo foi evidenciada maior resistência à penetração de raizes. Neste sentido, RoTH et alii (1986) verificaram uma correlação posi tiva entre a estabilidade de agregados e a infiltração total de água no solo. 


$$
\text { GROHMANN \& ARRUDA (1961) e OLIVEIRA \& SILVA }
$$

(1982) mencionam que o aumento no número de mobilização dos solos agrícolas, através do preparo, acarreta uma redução da proporção de macroagregados e um acréscimo de microagregados, caracterizando, assim, a degradação da estrutura do solo.

0 manejo e o tipo de cultura influenciam diretamente as condições físicas do solo. Segundo ALDERFER \& MERKLER (1941), quando os solos são cultivados há uma significativa alteração estrutural, que é maior quando o preparo é intensivo no sistema de produção agrícola. Entretanto, é possível, segundo esses autores, manter as condições físicas comparáveis às de solos sob floresta se forem tomadas precauções e adotado um programa de manejo para manutenção da atividade biológica no solo; a freqüente adição de matéria orgânica na forma de esterco ou de restos culturais, bem como a adubação verde, é prática indispensável para se atingir esse objetivo. CASSOL (1984) relata que na manutenção ou recuperação das condições físicas do solo, os restos de culturas devem ser picados e mantidos sobre a superfície do solo. O autor enfatiza a importância da rotação de culturas e do menor revolvimento do solo,pois, quando do apodrecimento das raízes, formam-se canais que poderão contribuir para um incremento na taxa de difusão de oxigê nio e na de infiltração de água. Porém, isso será verdadeiro desde que estes canais cheguem até a superfície do solo sem obstrução. 


\subsection{Recuperação de solos degradados}

\subsubsection{Efeito da matéria orgânica e da cobertura vegetal}

Com relação ao efeito da matéria orgânica, considera-se que só a fração coloidal (húmus), constituída principalmente por ácidos húmicos (50 a 80\%) e polissacarídeos (10-30\%) influi significativamente na maioria das propriedades físicas, químicas e biológicas do solo, tais como: melhoria na estabilidade da estrutura; aumento da permeabilidade, da capacidade de absorção d'água; da capacidade de troca de cátions (CTC); da disponibilidade de elementos essenciais ao desenvolvimento das plantas e, do poder de tamponamento e redução das perdas de íons nutrientes por lixiviação. Já a fração não humificada é principalmente uma importante fonte de alimento e energia para os macro e microorganismos, além de estimular o crescimento de raízes.

Esses efeitos podem ser mais ou menos acentuados, dependendo do estado e da natureza da matéria orgânica. Isso porque o húmus produz substâncias inibidoras ou ativadoras de crescimento do organismo, atuando, também, na liberação de elmentos como carbono, hidrogênio, oxigênio, nitrogênio, fósforo, enxofre e boro, principalmente. Contribui, ainda, para a redução da atividade do alumínio,manganês e cobre, diminuindo, assim, os efeitos tóxicos desses elementos, pela formação de complexos. 
LASSUS (1990) menciona a existência de duas formas muito distintas de matéria orgânica no solo: a matéria orgânica leve (mais grosseira, sendo constituída de restos de vegetais em início de decomposição, ainda ligada à fração mineral do solo) e uma segunda forma. denominada matéria orgânica difusa (intimamente ligada à maioria dos constituintes, minerais).

Da caracterização química da matéria orgânica leve (MOL) resultam três grupos de substâncias amplamente majoritárias, constituintes da parede celular vegetal, ou seja, as celuloses, as ligninas e as hemiceluloses. As celuloses e hemiceluloses são polímeros insolúveis, cuja hidrólise produz açúcares simples e constituem os carboidra tos estruturais dos vegetais. As ligninas são substâncias ternárias polimerizadas que cimentam entre si certas fibras celulósicas e que, no solo, formam complexos com aminoáci dos e outras substâncias, dando origem a materiais do tipo húmus, muito resistentes à ação dos agentes de degradação ( ALLISON, 1973).

Segundo LASSUS (1990), nas zonas tropicais, onde os processos de estabilização microbiológica da matéria orgânica são relativamente rápidos, a quantidade, bem como a composição da matéria leve, pode ser relevante quando se procura estabelecer sistemas de culturas adaptados à recuperação e conservação dos solos. Isso porque a constituição dos restos culturais incorporados tem influência so- 
bre as características físicas, químicas e biológicas do solo (DUCHAUFOR, 1979).

A ação da matéria orgânica sobre a estabilidade da estrutura diz respeito a modificações na coesão e molhabilidade (HÉNIN et alii, 1976). Contudo, o efeito da matéria orgânica está diretamente relacionado aos constituintes do húmus - ácidos húmicos e fúlvicos - como também à humina, que apresenta grande resistência à destruição pelos microorganismos, tendo, por consegüinte, ação muito durável no solo. Segundo HÉNIN et alii (1976), o efeito da matéria orgânica sobre a estrutura do solo é alcançado por intermédio das longas moléculas orgânicas, tais como os poliacrilatos, que agem diretamente sobre as forças de coesão. Essas moléculas têm efeito prolongado sobre a estrutura, de maneira diferente de substâncias transitórias, provenientes da atividade da macro e microflora do solo. Assim, molécu las orgânicas menos resistentes à ação dos microorganismos não podem ser consideradas como agentes cimentantes do solo com uma ação prolongada porque são eliminadas durante o processo de decomposição.

Observa-se, dessa forma, que os resíduos da adubação verde têm ação considerável sobre a estabilidade da estrutura, com efeitos de curta duração, enquanto que as palhas de cereais, mais resistentes à decomposição, têm um efeito mais duradouro. O efeito do esterco sobre a estabilidade da estrutura manifesta-se por longo período. Pode-se 
observar, assim, que essa estabilidade está diretamente relacionada com a composição química da matéria orgânica, bem como com os fatores determinantes da taxa de decomposição.

Neste sentido, MINHONI et alii (1990) relatam que a velocidade de decomposição reflete o grau de biodegradabilidade do material orgânico adicionado; material mais simples, como glicose e vinhaça, é mais rápido e facilmente degradado do que a palha de soja, o milho ou o bagaço de cana-de-açúcar.

Além da importância para as propriedades físicas do solo, a matéria orgânica influencia também suas características químicas e biológicas. A capacidade de troca de cátions e a soma de bases são aumentadas pela mineralização da matéria orgânica e posterior liberação de cátions e ânions (COSTA, 1983).

ALLISON ( 1973) menciona que a matéria orgâ nica contribui para o aumento da infiltração, além de reduzir as perdas de água por evaporação. Segundo o mesmo autor, solos de textura fina têm a sua drenagem aumentada com o emprego da matéria orgânica; isso torna maior o volume de solo explorável pelas raízes, aumentando a eficiência do uso da água e de nutrientes pelas plantas.

BAVER (1972) observou uma correlação direta entre a porcentagem de agregados maiores que $0,1 \mathrm{~mm}$ estáveis em água com o teor de carbono orgânico de vários solos. 
De acordo com o mesmo autor, verificam-se correlações entre carbono orgânico e a agregação em solos com menos de $25 \%$ de argila.

COSTA (1983) menciona que a associação de substâncias húmicas com a argila favorece a formação de agregados, através da gradual coalescência provocada pelo processo de desidratação. 0 mesmo autor relata que a presença de óxidos de ferro e alumínio contribui para que ocorra a ligação de substâncias húmicas com argila. Nesse mesmo raciocínio, ALLEXANDROVA (1960) menciona que a maior estabilidade e agregação estão relacionados com as forças de Van der Waals; a ação destas é incrementada pela desidratação, que favorece a aproximação das partículas do solo. Neste sentido, KIEHL (1979) relata que a matéria orgânica, juntamente com os minerais de argila,são os dois agentes cimentantes mais eficazes na agregação do solo. Deve-se considerar, ainda, segundo o mesmo autor, a contribuição de sesquióxidos de ferro e alumínio, assim como os cátions adsorvidos e o manejo do solo.

A manutenção da cobertura morta no solo vemse demonstrando eficiente na conservação das propriedades e do estado natural do solo, como também na recuperação de suas propriedades por vezes modificadas.

Segundo SKERMAN (1977), a recuperação de solo degradado pode ser alcançada através de cobertura vege- 
tal com espécies que tenham facilidade de estabelecimento, rápido desenvolvimento de cobertura agressividade suficente para controlar invasoras e melhorar as condições físicas e a fertilidade do solo. LAL (1979) complementa que essas espécies devem ser tolerantes a longos períodos de estiagem, ser facilmente eliminadas e não competir com a cultura subseqüente em sistema de rotação, ou com a cultura principal, em sistema de consorciação. Este mesmo autor afirma que,com a utilização de espécies vegetais que tenham este potencial, associada ao empregao de práticas agronômicas simples e eficientes, é possível, em curto prazo, melhorar as propriedades físicas, químicas e biológicas de solos degrada dos, aumentando a sua produtividade. Estas práticas resumem-se na manutenção de solo coberto com plantas ou resíduos destas, durante o maior tempo possível, na rotação e/ ou consorciação de culturas adequadas ao plantio direto e no controle de pragas e invasoras.

A eficiência da cobertura vegetal ou residual do solo no controle da erosão hídrica e na recuperação de solo degradadp está relacionada diretamente com a espécie, levando-se em conta a rapidez com a qual as plantas cobrem - solo e a quantidade e qualidade dos resíduos produzidos. Daí a importância de se procurar introduzir nos sistemas de culturas espécies capazes de cobrir o solo rapidamente (MEDEIROS, 1985) . 
A cobertura do solo proporcionada por resíduos de restos culturais atua sobre a conservação da água no solo de duas formas: protege a superfície contra a formação de crostas, aumentando a taxa de infiltração (DULEY, 1939), e reduz a taxa de evaporação pela reflexão de energia radiante (BAVER et alii, 1972). Outro efeito importante da cobertura é observado na temperatura do solo. BRAGAGNoLO \& MIELNICZUK (1990) relatam que a aplicação de palha de trigo na superfície do solo reduziu a temperatura máxima a 5 cm de profundidade, em média de 0,6 a $1,13^{\circ} \mathrm{C}$, dependendo da insolação e umidade do solo. De acordo com esses autores, a dose de 7,5 t/ha de palha de trigo aplicada em solo descoberto proporcionou uma redução da temperatura de 37,1 para $28,6^{\circ} \mathrm{C}$.

A cobertura do solo com resíduos vegetais pode trazer algumas desvantagens, principalmente no que diz respeito a pragas e doenças. A permanência dos resíduos na superfície cria um ambiente favorável para o desenvolvimento de determinados insetos e patógenos (B00salis \& COOK, 1973; MUSICK \& BEASLEY, 1979). Além desses efeitos negativos, o efeito alelopático de substâncias fitotóxicas exis tentes nos resíduos ou produzidos durante a decomposição destes é outro fator preocupante no uso de resíduos para a cobertura do solo (ELLIOT et alii, 1978). A rotação de culturas pode ser uma opção para minimizar e esses efeitos negativos provocados pela cobertura morta, além de trazer outros benefícios ao solo. 


\subsubsection{Efeito da rotação de culturas}

Todo e qualquer sistema de preparo do solo e plantio somente pode atingir a máxima eficiência se combinado com uma rotação adequada de culturas, incluindo a aduba ção verde em época de pousio. A rotação de culturas, segundo DALLA ROSA (1981), contribuiu para o aumento do rendimento das culturas, influenciando nos seguintes aspectos: redução das perdas de solo, controle de ervas daninhas, controle de pragas e doenças, redução dos custos de adubação, melhor aproveitamento de máquinas e mão-de-obra, redução de risco em um sistema tecnicamente organizado e aumento dos teores de matéria orgânica e nitrogênio do solo. Deve-se destacar, também, que sistemas monoculturais empregados sucessivamente tendem a promover ação seletiva sobre a população de fungos (VIDOR, 1984). Assim, pode-se observar que a diversificação

de culturas é de extrema importância para melhorar as propriedades físicas, químicas e biológicas do solo.

CARPENEDO \& MIELNICZUK (1990) mencionam que a vegetação e seus resíduos protegem os agregados da superfí cie contra a desagregação pelo impacto da chuva e variações bruscas de temperatura. Ao mesmo tempo, o continuo forneci mento de material orgânico, quer por secreções radiculares, quer por renovação do sistema radicular e da parte aérea, ou ainda, pela disposição de resíduos de colheitas, serve de fonte de energia para atividade microbiana, cujos subprodu tos, constituídos de moléculas orgânicas em diversas fases 
de decomposição, atuam como agentes de formação e estabilização dos agregados (ALLISON, 1973; HARRIS et alii, 1966). Ao lado desses benefícios, o efeito mecânico das raízes sobre a formação de zonas de depleção de água e acumulaçäo e precipitação de sais, decorrentes de fluxos provocados pela atividade da planta, são fenômenos importantes na formação e estabilização de agregados em zonas adjacentes às raízes (BRADFIELD, 1973; ALLISON, 1973). Neste sentido, os mesmos autores demonstraram que a presença por quatro anos de pastagem de desmódio, siratro e setária, resultou em melhoria na qualidade estrutural de um Latossolo Roxo na profundidade de 0 a 5 cm, em relação ao preparo convencional com sucessão trigo-soja.

A introdução de culturas de cobertura com alto potencial produtivo e recuperador do solo, sejam isoladas ou consorciadas, pode melhorar a ação benéfica da rotação e torná-la uma prática efetiva e econômica de recuperação de solos degradados. Nesses solos, torna-se necessário o uso de espécies que tenham o sistema radicular denso, capaz de penetrar em camadas compactadas, reciclar nutrientes e melhorar a estrutura do solo (MEDEIRos, 1985). Para isso, a utilização de gramíneas e leguminosas consor ciadas para a cobertura em rotação é desejável (ADANS \& BARNETT, 1965; LAL, 1974 ).

$$
\text { MEDEIROS (1985) identificou três sistemas de }
$$
culturas com grande potencial produtivo, recuperador e con- 
servador de solo. Para pequena propriedade, o autor recomenda milho+caupi / aveia+vica / milho+caupi; milho+lablab / pousio com lablab / milho+lablab; como sistema adicional, recomenda milheto / aveiattrevo / milho, podendo este ser adaptado tanto para grandes como para pequenas explorações agro-pastoris.

BARBER (1959), comparando a agregação do solo em parcelas cultivadas com milho seguido de pastagem, com parcelas cultivadas continuamente com milho, concluiu que a alternância de pastagem com milho melhorou significativamente a estrutura do solo, reforçando, portanto, a importância da rotação de culturas.

Segundo RUSSEL (1973), a estrutura mais estável do solo ocorre quando há consorciação de gramíneas e leguminosas, porque elas se completam. As gramíneas dão maior quantidade de biomassa, enquanto as leguminosas melhoram a relação carbono/nitrogênio, que acelera a decomposição. As raízes das leguminosas penetram a grandes profundidades e melhoram a permeabilidade do solo. As gramíneas, por sua vez, com suas raízes fibrosas e fasciculadas, atuam mais na estabilidade de agregados e tornam mais permeável a camada arável. Neste sentido, UHLAND (1949), após 12 anos de cultivo de associação de diferentes espécies de gramíneas em solo franco-siltoso, obteve redução da densidade do solo de 1,31 para $1,00 \mathrm{~g} / \mathrm{cm}^{3}$ na profundidade de 0 a $15 \mathrm{~cm}$. 
Segundo LASSUS (1990), a permanência de maiores quantidades de matéria orgânica no solo (matéria orgânica leve) está relacionada à presença de leguminosas na sucessão de culturas, como guandú/milho, vica/milho+caupi e aveia+tremoço+milho.

WUTKE \& ALVAREZ (1968) estudaram o efeito da adubação verde anual com Crotalaria juncea L. no aumento da produtividade de milho e nas propriedades de um Latossolo Vermelho Amarelo Húmico. No que diz respeito à parte física do solo, após três anos, os referidos autores não observaram efeito da adubação verde na estrutura do solo em estudo, com base na análise da distribuição dos agregados estáveis em água.

RESCK \& PEREIRA (1970) estudaram os efeitos da incorporação de restos culturais de milho (Zea mays L.) , soja (Glycine max (L.) Merril) e sorgo (Sorghum bicolor (L.) Moench) e adubação verde com mucuna preta (Stizolobium atterrimum Piper e Tracy) sobre a capacidade de retenção de água de um Latosoolo Vermelho Amarelo de textura argilosa.os autores, constataram que não houve variação significativa nos valores de retenção de água, porém verificou-se uma tendên cia de diminuição após a incorporação dos restos culturais e adubo verde. Parâmetros tais como densidade aparente (densidade do solo) e real (densidade de partículas) e porosidade total, foram determinados antes e após a incorporação, não hsvendo também diferenças significativas. 
MANNERING et alii (1964), estudando o efeito da cultura do milho em rotação com aveia consorciada com trevo e pastagem constituída de capim azul (Poa pratense) + alfafa, sobre as propriedades físicas do solo e perdas por erosão, observaram que um ou dois anos de pastagem perene precedendo o milho foi mais eficiente do que aveia+trevo na redução de perdas de solo, as quais foram diretamente relacionadas com a agregação do solo. Ds autores correlaciona ram o índice de agregação com a infiltração de água no solo. confirma-se, assim, a essencialidade da rotação de culturas na reucperação das propriedades físicas do solo e no controle da erosão.

Já CARPENEDO (1985), estudando o efeito de diferentes sistemas de cultivo (sucessões trigo-soja em plantio direto e convencional; rotação com trigo, soja,tremoço, milho e aveia, e pastagem constituída de siratro,desmódio e setária), sobre a agregação dos solos Santo Angelo (Latossolo Roxo distrófico) e Erexim (Latossolo Roxo álico), observou que o tratamento com pastagem por 3,5 anos apre sentou significativo aumento na agregação do solo em relação ao tratamento com a sucessão trigo-soja em preparo convencional pelo mesmo período. Além do melhoramento da estrutura do solo, o autor verificou que a pastagem propor cionou significante aumento no teor de matéria orgânica na profundidade de 0 a 5 cm. Este incremento foi de 4,0\% para 5,0\% no solo Erexim e de 4,0\% para 4,3\% no solo Santo Ange10. 


$$
\text { Segundo SHIH-CHUNG e CHIN-CHEN (1970), nas }
$$

regiões úmidas temperadas, tais como as áreas "podzolizadas", e nas regiões quentes, tais como as áreas de solos "lateríticos", a adubação verde pode incrementar a produtividade. Entretanto, no primeiro e no segundo caso, tem-se, respectivamente, pequeno e nenhum aumento no teor de matéria orgânica no solo e disponibilidade de nutrientes. Geralmente, a adubação verde tem um maior efeito sesidual nas .. regiões mais frias do que nas mais quentes devido à velocidade de decomposição do adubo verde; em solos leves (textura arenosa) tem-se encontrado melhor resposta à adubação verde do que em solos pesados (textura argilosa), sob as mesmas condições de clima.

WUTKE \& ALVAREZ (1968) mencionam que as leguminosas são mais eficazes na capacidade de extração de cátions bivalentes do solo'; por consegüinte, pode existir um agravamento nas deficiências desses minerais (principalmente cálcio e magnésio), se a leguminosa incorporada não liberar, para a cultura següinte, em tempo hábil, os nutrientes extraídos.

VIEGAS et alii (1960a) estudaram o efeito da adubação verde anual com mucuna preta (Stizolobium atter rimum Piper e Tracy) pelu período de dez anos, em algumas características químicas de três diferentes solos de São Paulo (Arenito de Bauru, Glacial e Terra Roxa Misturada).Não 
houve efeito da adubação verde no teor de alumínio do solo, e, com relação ao pH, apenas a Terra Roxa Misturada apresentou um decréscimo.

MELLO \& BRASIL SOBRINHO (1960b) estudaram, em casos mantidos em casa-de-vegetaçäo, o efeito da incor poração de resíduos de mucuna preta (Stizolobium atterrium Piper e Tracy), Crotalaria juncea L. e feijão baiano (Vigna sesquipedalis W.F. Wight) sobre o teor de cálcio trocável de um solo arenoso. Verificaram que, para as duas primeiras leguminosas, houve um aumento significativo neste teor,cerca de quatro meses após a incorporação dos resíduos.

$$
\text { CAMARGO et alii (1962) estudaram a influên - }
$$
cia da adubação verde com Crotalaria spectabilis Roth e Secale cereale L., nas caracteristicas químicas de uma Terra Roxa e de um Latossolo Vermelho-Amarelo. Verificaram, após cinco meses, que não houve efeito significativo da adubação verde nos teores de fósforo, potássio e cálcio daqueles solos.

MASCARENHAS et alii (1977), incorporando Crotalaria juncea L. em um Latossolo Roxo e Latossolo VermeIho Escuro orto, verificaram um aumento no teor de potássio e nenhuma influência no teor de potássio e nenhuma influên cia no teor de fósforo do solo quatro meses após a realização da prática. 
VITTI et alii (1979) estudaram a influência de alguns adubos verdes (Dolichos lablab L., Stizolobium de eringianum Bort e Canavalia ensiformis DC) na fertilidade de um Latossolo Vermelho fase arenosa. Em todas as épo cas de amostragem (três, seis, nove e doze meses após incorporação) e, para todas as leguminosas estudadas, os teores de cálcio, magnésio e fósforo solúvel encontrados nas parcelas com adubo verde eram estatisticamente menores que aqueles encontrados na testemunha. Dessa forma, a adubação verde contribuiu para diminuir a disponibilidade desses nutrientes no solo, nas condições estudadas.

\subsubsection{Efeito de práticas.consexvacionistas}

A recuperação de solos fisicamente degrada dos pelo cultivo pode ser obtida através de práticas vege tativas e mecânicas. As práticas vegetativas consistem no emprego de plantas que possuam sistema radicular com capacidade de recuperação da estrutura e penetraçao em camadas compactadas do solo. São utilizadas em sistemas de rotação de culturas, com o aproveitamento dos restos culturais complementados com adubação orgânica. Entre as práticas mecânicas encontram-se a lavra, a escarificação, a gradagem e a subsolagem.

A utilização de métodos mecânicos e vegeta tivos isoladamente vem-se demonstrando ineficiente, ao pas- 
so que a combinação desses métodos tem atingido de maneira satisfatória os objetivos de recuperação dos solos (DALLA ROSA, 1981).

0 rompimento de camadas compactadas se faz através de práticas mecânicas como gradagens, aração, escarificação e subsolagem. Estas operações são mais eficientes quando a umidade do solo encontra-se no ponto de friabili dade. Após o trabalho mecânico, o solo pode ser plantado o mais rapidamente possível (DERPSCH, 1983).

MEDEIROS (1985) obteve resultados significativos na recuperação física de um solo Laterítico BrunoAvermelhado, usando aração profunda para rompimento da camada compactada, integrada com a rotaçao de culturas incluindo gramíneas e leguminosas. A rotação de culturas,prin.cipalmente com gramíneas e leguminosas, contibuiu para o melhoramento das propriedades físicas e químicas do solo, auxiliou o controle da erosão e incrementou os rendimentos culturais. Dessa forma, caracteriza-se por ser uma prática promissora e vantajosa, tanto do ponto de vista econômico como do conservacionista. 


\subsubsection{Efeito da adubação e da calagem na agregação do solo}

A estabilidade de agregados é influenciada pela natureza dos cátions trocáveis, pela interação de partí culas de argila, pela presença de matéria orgânica e pela ação das raízes e dos macro e microorganismos (BAVER, 1972). Os cátions trocáveis provenientes da aplicação de corretivos e fertilizantes contendo N-P-K, principalmente, podem contribuir de maneira direta ou indireta para a estruturação do solo.

A correção da acidez e o formecimento de íons nutrientes ao solo proporciona crescimento maior e mais rápido das plantas e, conseqüentemente, maiores rendimentos ; além disso, assegura maior produção de biomassa (restos culturais), incrementando o aporte de matéria orgânica so solo.

A -matéria orgânica e as argilas, quando se associam a determinados cátions, parecem atuar como agentes cimentantes, além dos óxidos e hidróxidos de ferro e alumí nio que podem estabilizar partículas (GAVANDE, 1973; BRADY, 1979).

Alguns autores (MARTIN \& WARSMAN, 1940 e 1941; BROUNING \& MILAN, 1944) observaram efeitos significa tivos da aplicaçáo de calcário, tanto como fonte de cálcio e magnésio, como corretivo da acidez do solo. Além disso, o calcário proporcionou maior desenvolvimento vegetativo de 
raizes, caules e folhas, resultando maior contribuição de matéria orgânica incorporada ao solo. Esses autores obser varam, ainda, um estímulo da aplicação de calcário na atividade microbiana, responsável pela produção de substâncias cimentantes. Por consegüinte, dá-se a melhoria na estabilidade e no tamanho dos agregados. A atividade biológica, reconhecida como fator responsável pela decomposiçào da matéria orgânica e pela agregação, é afetada pelas condições de $\mathrm{pH}$ e disponibilidade de nutrientes. As bactérias e os actinomicetos normalmente são favorecidos pela calagem por apresentarem o máximo de crescimento e atividade na faixa de pH 6,0 a 7,0, enquanto para os fungos essa faixa é de pH 5,0 a 6,0 (VIDOR, 1984). De acordo com HARRIS et alii (1964) e WATSON \& STOJANOVIC (1965), a estabilidade dos agregados maiores está associada à presença de fungos e actinomicetos, enquanto a formação de pequenos agregados estáveis é creditada à presença de bactérias.

Segundo BALDISSERA (1985), a correção da acidez e da fertiilidade do solo melhora a disponibilidade de vários nutrientes e incrementa a atividade de bactérias fixadoras de nitrogênio. Esses benefícios são refletidos no desenvolvimento das culturas, além de aumentarem a quanti dade de matéria orgânica adicionada ao solo e a atividade de microorganismos, que, por sua vez, contribuem para a melhoria das propriedades físicas do solo. 
GHANI et alii (1955), estudando o efeito da adição de $\mathrm{CaCO}_{3}$, $\operatorname{CaSO}_{4}$ e MgO na agregação de um solo laterítico após 4, 8, 12 e 16 semanas de incorporação, observaram que o $\mathrm{CaCO}_{3}$ promoveu tanto a agregação como a dispersão nos estágios iniciais, mas nos estágios finais a agregação prevaleceu e os agregados mantiveram-se mais ou menos estáveis. Estes mesmos autores observaram, ainda, que o Caso 4 é mais eficiente em promover a agregação do que o $\mathrm{CaCO}_{3}$, e este mais que o Mgo.

Já ELSON \& LUTZ (1940), estudando o efeito do cálcio, adicionado na forma de superfosfato, encontraram um decréscimo na estabilidade dos agregados do solo. De acordo com esses autores, esse decréscimo na agregação pode estar relacionado à formação de humatos de cálcio e magnésio, que são agentes menos eficientes que humatos de hidrogênio, ferro e alumínio.

MARTIN \& WAKSMAN (1941), analisando o efeito do calcário e de diferentes resíduos orgânicos (alfafa, trigo e esterco) na ageegação do solo, concluiram que o calcário aplicado juntamente com resíduos orgânicos causa maior agregação do que o calcário ou os resíduos orgânicos isola damente.

CERQUEIRA (1984), em experimento de casa-de vegetação, não observou efeito da incorporação de palha de trigo e da mudança do pH de um Latossolo Vermelho-Escuro, no diâmetro médio dos agregados. 
Vários trabalhos têm demonstrado que a adição de calcário em solos ácidos diminui a floculação das particulas de argila, o que conduz à hipótese de que a calagem estaria contribuindo para a degradação desses solos. Por outro lado, a calagem pode contribuir positivamente para a recuperação do solo através da maior quantidade de biomassa que propicia e do aumento da atividade microbiana.

Portanto, as características químicas, como $\mathrm{pH}$, natureza e concentração de cátions adsorvido, têm influência no processo de floculação e dispersão e, por conseguinte, na agregação dos solos. Neste sentido, SCHEFFER \& CHACHTSCHABEL (1979) indicam que em solos com pH acima de 7,0 e com alta saturação de cálcio há menor quantidade de argila dispersa e maior estabilidade de agregados do que em solos com pH entre 5,0 e 7,0, onde o cálcio se encontra em menor concentração: Pnr outro lado, à medida que o solo se torna ácido ( pH mẹnor que 5,0 ), a concentração de alumínio aumenta e a dispersão da argila diminui, indicando que a estabilidade drs agregados novamente aumentou.

Ressalta-se, ainda, que os agregados tos solos em presença de argilas montmorilonitas são pouco estáveis em água e os com argilas cauliníticas são mais estáveis, estando a ilita em posição intermediária (BERTONI \& LOMBARDI NETO, 1985). 


\section{MATERIAL E MÉTODOS}

\section{1. Área experimental}

\subsubsection{Localização}

A área experimental onde se desenvolveu o presente projeto de pesquisa encontra-se localizada na Fazenda Piloto do Departamento de Ciências Agrárias da Universidade de Taubaté (UNITAU). A Fazenda Piloto está situada na Bacia de Taubaté (Vale do paraíba), no Município de Taubaté (SP), a $45^{\circ} 31^{\prime} 02^{\prime \prime}$ oeste de longitude e, $23^{\circ} 02^{\prime} 34^{\prime \prime}$ sul de latitude, e a uma altitude de 577 metros.

\subsubsection{Clima regional}

SETZER (1946) classificou o clima com base em Köppen, de quente com inverno seco (Cwa), abrangendo provavelmente as várzeas e todo o terciário da Bacia de Taubaté.A média anual de temperatura é de $21^{\circ} \mathrm{C}$, enquanto a média do mês mais frio situa-se entre 16 e $17^{\circ} \mathrm{C}$. Nas serras as temperaturas médias anuais são menores, caindo para $15^{\circ} \mathrm{C}$ ou menos, acima de 2000 metros de altitude. O mês mais quente é fevereiro e o mês mais frio é julho. De acordo com Thorntwaite,o clima é da classe C2rB'4, correspondente a um clima úmido, 
com pequeno déficit hídrico, mesotérmico e com vegetação - ano todo.

0 balanço hídrico local (dados de 5 anos de observações) mostra que a média anual de precipitação plu vial é de $1380 \mathrm{~mm}$, com excedentes nos meses de janeiro, fevereiro e março e déficit em julho e agosto.

\subsubsection{Solo}

As formações geológicas do Vale do Paraíba são sedimentos, destacando-se arenitos com cimento calcário, arenitos com cimento argiloso, argilitos, folhelhos, varvitos e tilitos.

De acordo com VERDADE et alii (1957), o solo que ocorre na área experimental é um Latossolo Vermelho Amarelo, Série Ipiranga, fase terraço, de textura média/argilosa, originalmente bem drenado, ocorrendo em relevo ondulado ( 8 a $20 \%$ de declividade).

\subsection{Experimento}

0 experimento constou de dez tratamentos compreendendo diferentes seqüências de cultura de verão e inverno (Tabela 1). o delineamento experimental utilizado foi o de blocos ao acaso, com três repetições, possuindo cada unidade experimental uma área total de $78,0 \mathrm{~m}^{2}(13,0 \mathrm{~m}$ $\times 6,0 \mathrm{~m})$. 


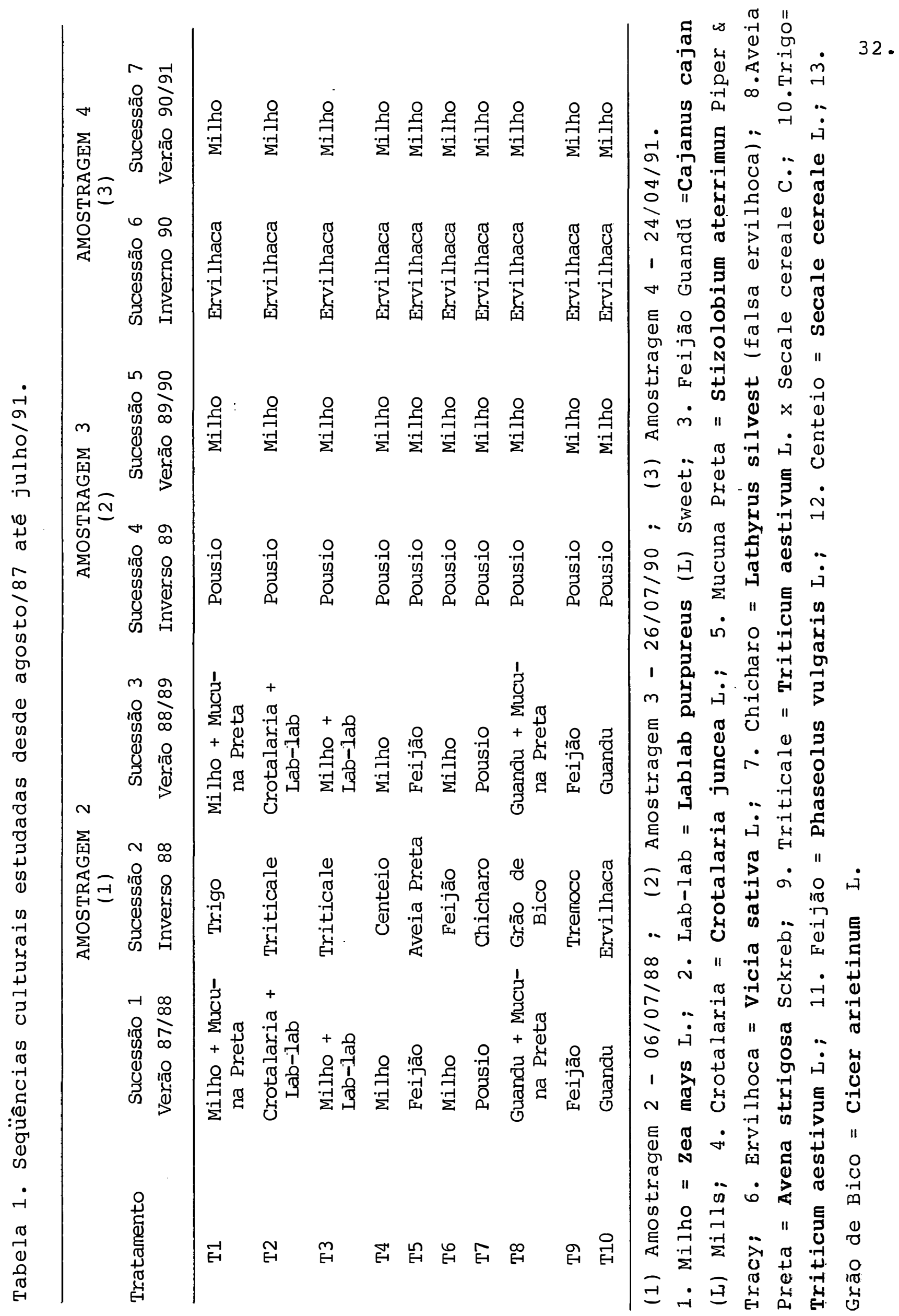


Antes da instalação do experimento, em 12/ 08/87, efetuou-se uma caracterização química e física da área experimental (amostragem no 1) através de análises de amostras coletadas nas profundidades de 0 a 20 e de 20 a 40 cm (Tabela 2).

Em 26/09/87, com base no teor de alumínio trocável, efetuou-se a correção da acidez do solo com calcário dolomítico (PRNT $=68 \%$ ), na quantidade de 7,2 t/ha,incorporando-o mecanicamente. No dia 28/10/87 realizou-se uma adubação de plantio com $75 \mathrm{~kg} / \mathrm{ha}$ de $\mathrm{P}_{2} \mathrm{O}_{5}$ (superfosfato simples) e $50 \mathrm{~kg} / \mathrm{ha}$ de $\mathrm{K}_{2} \mathrm{O}$ (cloreto de potássio), aplicados mecanicamente. Em seguida, procedeu-se à implantação das culturas de verão (Tabela 1). A adubação de plantio para as demais seqüências culturais foi efetuada sempre com base na análise de solo. Em 06/07/88 realizou-se a 2a amostra gem de solo, nas profundidades de 0-20 e 20-40 cm, objeti vando a caracterização físico-química de todas as unidades experimentais.

Para a implantação da sucessão de número 5 , realizou-se em 26/12/89 uma aração profunda (a $30 \mathrm{~cm}$ de profundidade), seguida de duas gradagens em 27/11/89.

Em 02/02/90 efetuou-se uma adubação com 435 $\mathrm{kg} / \mathrm{ha}$ da fórmula 4-14-8 e o plantio do milho (cultivar HMD-8214). A adubação de cobertura e os demais tratos culturais foram realizados em 23/03/90, e na ocasião aplicouse $40 \mathrm{kh} / \mathrm{ha}$ de $\mathrm{N}$ sulfato de amônio) em cobertura. 
Tabela 2 - Propriedades físicas e químicas de um Latossolo Vermelho-Amarelo em duas profundidades, antes da implantação do experimento (setembro/87).

\begin{tabular}{|c|c|c|c|c|c|c|c|c|c|c|}
\hline $\begin{array}{l}\text { Profun } \\
\text { didade } \\
\mathrm{cm}\end{array}$ & $\begin{array}{l}\text { Dens } \\
\text { S. } \\
\text { g/ }\end{array}$ & $\begin{array}{c}\text { idade } \\
\mathrm{Cm}^{3}\end{array}$ & $\begin{array}{l}\text { Grar } \\
\text { Arg. }\end{array}$ & $\begin{array}{l}\text { ulon } \\
\text { Siz. } \\
(\%)\end{array}$ & $\begin{array}{l}\text { tria } \\
\text { A.T. }\end{array}$ & $\begin{array}{c}\text { D.M.P. } \\
\mathrm{mm}\end{array}$ & $\begin{array}{c}\text { P.T. } \\
\%\end{array}$ & $\begin{array}{c}U .9 . \\
\%\end{array}$ & $\begin{array}{c}P . \\
\text { resina } \\
\text { ug/cm }\end{array}$ & $\begin{array}{c}\text { M.O. } \\
\%\end{array}$ \\
\hline $0-20$ & 1,31 & 2,56 & 42 & 13 & 45 & 5,23 & 46 & 16 & 7 & 2,0 \\
\hline $20-40$ & 1,51 & 2,58 & 57 & 13 & 30 & 5,03 & 41 & 18 & 4 & 1,2 \\
\hline
\end{tabular}

\begin{tabular}{|c|c|c|c|c|c|c|c|c|c|c|}
\hline \multirow{2}{*}{$\begin{array}{l}\text { Profun } \\
\text { didade } \\
\mathrm{cm}\end{array}$} & \multicolumn{2}{|c|}{$\mathrm{pH}$} & $\mathrm{K}$ & $\mathrm{Ca}$ & Mg & $\mathrm{H}+\mathrm{Al}$ & Al & 5 & $T$ & v \\
\hline & $\mathrm{H}_{2} \mathrm{O}$ & $\mathrm{CaCl}_{2}$ & \multicolumn{7}{|c|}{ meq/100 $\mathrm{cm}^{3}$} & $\%$ \\
\hline $0-20$ & 5,2 & 4,6 & 0,14 & 1,50 & 0,50 & 3,07 & 0,81 & 2,14 & 5,21 & 41 \\
\hline $20-40$ & 4,9 & 4,1 & 0,08 & 0,90 & 0,30 & 3,74 & 2,44 & 1,28 & 5,02 & 26 \\
\hline
\end{tabular}

(s) Solo

(P) Partículas

(DMP) Diâmetro Médio Ponderado

(PT) Porosidade Total

(Ug) Umidade Gravimétrica 
Em 25/07/90 foram efetuadas amostragens de solo em todas as parcelas ( 3 a amostragem), objetivando a caracterização química e física de todas as unidades expe rimentais. Durante o processo de amostragem, observou-se a presença intensa de raízes de milho na profundidade de 20$40 \mathrm{~cm}$. No dia 26/07/90, realizou-se a colheita do milho em plantas situadas no centro de cada unidade experimental, utilizando-se uma área útil de $6 \mathrm{~m}^{2}(3,0 \times 2,0)$. Em 31/07/ 90, procedeu-se à incorporação dos restos culturais do milho com auxílio de uma grade pesada, ficando a área experimental até a primeira quinzena de agosto em pousio.

Na segunda quinzena de agosto, efetuou-se o plantio da ervilhaca a lanço (sucessão de no 6). Em 26/08 / 90, o índice de germinação era de aproximadamente de 90\%.Em 14/11/90, realizou-se a incorporação da ervilhaca em todas as unidades experimentais, com auxílio da grade aradora. Em 23/11/90, após o preparo do solo da área experimental com uma grade niveladora, efetuou-se aplicação de 330 kg/ha da fórmula 4-14-8, procedendo-se o plantio do milho (sucessão no 7). Tornou-se necessário o replantio do milho em 12/12 / 90, seguindo-se duas adubações de cobertura na base de 20 kg/ha de N (sulfato de amônio), e tratos culturais que foram realizados respectivamente em 08/01/91 e 28/01/91. No dia 24/04/91 efetuou-se a 4a amostragem de solo, objetivando o levantamento final das características físicas e químicas de todas unidades experimentais. A colheita na sucessão de no 7 foi realizada em $25 / 04 / 91$. 


\subsection{Métodos de análise}

\subsubsection{Análises físicas}

Foram efetuadas as seguiintes determinações

físicas: distribuição do tamanho de agregados estáveis em água; macro e microporosidade, e porosidade total; densidade do solo e de partídulas; análise granulométrica e umidade do solo (médias de duas repetições).

\subsubsection{Distribuição do tamanho dos agrega- dos estáveis em água}

Para a determinação da distribuição de agregados estáveis em água, utilizou-se da técnica descrita por KEMPER \& CHEPIL (1965). Amostras coletadas em duas profundidades $(0-20$ e 20-40 cm), dentro de cada unidade experimental, foram fracionadas em agregados menores que $7,93 \mathrm{~mm}$ de diâmetro e maiores que $4,76 \mathrm{~mm}$ de diâmetro. As amostras foram secas ao ar e, após, tomaram-se duas subamostras de 25 g, as quais foram saturadas por pulverizações com álcool etílico. Em seguida, essas subamostras foram colocadas num jogo de cinco peneiras (4,76;2,00; 1,00; 0,50 e 0,25 mm de abertura de malha) e submetidas à agitação com 45 oscilações por minuto, durante 15 minutos, em um tanque de água. Os resultados obtidos na distribuição de agregados estáveis em água foram expressos pelo diâmetro médio ponderado (D.M.P.) proposto por VAN BAVEL (1949). 


\subsubsection{Macro e microporosidade, e porosi - dade total}

A porosidade do solo na área experimental (macro e microporosidade e porosidade total) foi quantifi cada por meio de mesa de tensão, com amostras coletadas nas profundidades de 0-20 e 20-40 cm, dentro de cada unidade experimental, com auxílio de anéis volumétricos metálicos, segundo procedimento descrito por KIEHL (1979).

\subsubsection{Densidade do solo e de partículas}

Para a densidade do solo, empregou-se a metodologia descrita por BLAKE (1965a), a qual emprega os mesmos anéis volumétricos utilizados na determinação de macro e microporosidade.

Para a determinação da densidade de partículas, utilizou-se o método descrito por fORSYTHE (1975), que emprega balões volumétricos de $250 \mathrm{ml}$, chapa aquecedora e água previamente fervida como fluído para a determinação do volume ocupado pelas partículas. Essas determinações foram realizadas para as profundidades de 0-20 e 20-40 cm, em duplicata, para todas as unidades experimentais.

\subsubsection{Análise granulométrica}

Determinou-se a textura do solo pelo método de BouYoucos, modificado por DAY (1965), segundo procedi - 
mento descrito por KIEHL (1979). Para a dispersão das partículas utilizaram-se $20 \mathrm{ml}$ de $\mathrm{NaOH} 1 \mathrm{~N}$ para $40 \mathrm{~g}$ de TFSA. A determinação de silte mais argila foi feita através de leitura com densímetro, e a distribuição granulométrica da fração areia por peneiragem.

\subsubsection{Umidade de campo}

A umidade de campo foi determinada gravimetricamente de acordo com o procedimento descrito por fORSYTHE (1975), sempre que se efetuou a coleta de terra para avaliação das unidades experimentais sob as diferentes sucessões culturais.

\subsection{Análises químicas}

Efetuou-se a caracterização química das unidades experimentais, nas profundidades de 0-20 e 20-40 cm, com amostras secas ao ar e peneiradas em malha de 2,00 mm. As análises químicas, efetuadas em duplicata, compreenderam: cátions trocáveis (cálcio, magnésio e potássio); fósforo extraído (P-resina); acidez potencial; alumínio trocável ; matéria orgânica; $\mathrm{pH}$ em $\mathrm{H}_{2} \mathrm{O}$ e em $\mathrm{CaCl}_{2}$.

Para a determinação dos cátions trocáveis, utilizou-se o método proposto por TEDESCO et alii (1985), que consiste na extração de cátions trocáveis com acetato de amônio 1N, pH 7,0, na proporção solo-extrator (1:10), e 
agitação por 60 minutos. As leituras de potássio foram realizadas em fotômetro de chama marca PROCYON e as leituras de cálcio e magnésio em espectrofotômetro de absorção atô mica marca C.G.A.A. 7000/ABC (duplo feixe). Antes da leitura de cálcio e magnésio, adicionou-se óxido de lantânio na proporção de 0,1\% para evitar interferência do alumínio.

0 teor de matéria orgânica no solo foi determinado pelo método WALKLEY-BLACK (ALLISON, 1965), por via úmida (oxidação do carbono orgânico pelo bicromato de potássio na presença de ácido sulfúrico).

A determinação do pH em água e em cloreto de cálcio foi efetuada por potenciometria em suspensão de solução e terra na relação 1:2,5 (TEDESCO et alii, 1985 e RAIJ \& QUAGGIO, 1985).

A acidez potencial ( $H+A l)$ foi realizada por potenciometria, com o uso da solução SMP, após determinação do $\mathrm{pH}$ em CaCl 2 , conforme RAIJ \& QUAGGIO (1985). 0 alumínio trocável foi extraído com KCl $1 \mathrm{~N}$ e determinado por titulo metria, conforme metodologia empregada pela EMBRAPA (1979).

o fósforo foi extraído pelo método da resina trocadora de ânios (RAIJ \& QUAGGIO, 1985) e determinado por leitura em espectrofotômetro 8-39 da MICRONAL.

Os dados obtidos através das análises físicas e químicas durante a condução do presente trabalho, para as profundidades de 0-20 e $20-40 \mathrm{~cm}$, foram submetidas à 
análise de variância, seguindo o delineamento de blocos ao acaso, sendo as médias comparadas pelo teste de Duncan a $5 \%$ • 


\title{
4. RESULTADOS E DISCUSSÃO
}

\subsection{Efeito de culturas sucessivas sobre as característi- cas químicas}

\begin{abstract}
A cobertura vegetal, viva ou morta, proporcionada por gramíneas e leguminosas, atua de maneira direta ou indireta nas características intrínsecas do solo. Como por exemplo, podemos destacar os processos físicos, químicos e biológicos do solo, alterando o teor de matéria orgânica.o complexo argilo-húmico, a capacidade de troca de cátions, a soma de bases trocáveis, a saturação em bases e a produção de substâncias inibidoras ou ativadoras de microorganismos também são afetados pela cobertura vegetal, podendo, dessa forma, contribuir para a estruturação do solo. Deve-se destacar, ainda, a reciclagem de nutrientes em profundidade pelas raízes e a maior produção de biomassa pelas seqüências culturais envolvendo gramíneas e leguminosas.
\end{abstract}

\subsubsection{Matéria orgânica}

Na Tabela 3 são apresentados os valores médios de matéria orgânica, nos diferentes tratamentos, em fun- 
Tabela 3. Porcentagem de Matéria Orgânica no solo, durante a con dução das diferentes sequêencias culturais.

\section{Matéria Orgânica (\%)}

\begin{tabular}{|c|c|c|c|c|c|c|}
\hline \multirow[t]{2}{*}{ Tratamento } & \multicolumn{2}{|c|}{$\begin{array}{l}\text { 2a Amostragem }{ }^{1} \\
\text { Profundidade }\end{array}$} & \multicolumn{2}{|c|}{$\begin{array}{l}3 \underline{a} \text { Amostragem } \\
\text { Profundidade }\end{array}$} & \multicolumn{2}{|c|}{$\begin{array}{c}4 \underline{a} \text { Amostragem }^{3} \\
\text { Profundidade }\end{array}$} \\
\hline & \multicolumn{2}{|c|}{$(\mathrm{cm})$} & \multicolumn{2}{|c|}{$(\mathrm{cm})$} & $0-20$ & $20-40$ \\
\hline $\mathrm{T} 1$ & $1,7^{\mathrm{a}}$ & $1,8^{a}$ & $1,9^{a}$ & $1,5^{a}$ & $2,2^{a}$ & $1,8^{a}$ \\
\hline T2 & $1,8^{a}$ & $1,4^{\mathrm{a}}$ & $2,1^{a}$ & $2,2^{a}$ & $2,1^{\mathrm{a}}$ & $1,8^{a}$ \\
\hline $\mathrm{T} 3$ & $1,4^{a}$ & $1,5^{\mathrm{a}}$ & $2,2^{a}$ & $1,8^{a}$ & $2,3^{a}$ & $1,9^{a}$ \\
\hline $\mathrm{T} 4$ & $1,7^{a}$ & $1,6^{\mathrm{a}}$ & $2,3^{a}$ & $1,7^{a}$ & $2,2^{\mathrm{a}}$ & $1,8^{a}$ \\
\hline T5 & $1,9^{a}$ & $1,6^{\mathrm{a}}$ & $2,2^{a}$ & $1,7^{\mathrm{a}}$ & $2,3^{a}$ & $1,7^{\mathrm{a}}$ \\
\hline T6 & $1,7^{a}$ & $1,9^{a}$ & $2,2^{a}$ & $1,6^{a}$ & $2,3^{a}$ & $1,8^{a}$ \\
\hline $\mathrm{T} 7$ & $1,5^{a}$ & $1,6^{a}$ & $2,2^{a}$ & $1,9^{a}$ & $2,2^{a}$ & $1,7^{a}$ \\
\hline T8 & $1,8^{a}$ & $1,6^{a}$ & $2,1^{\mathrm{a}}$ & $2,0^{a}$ & $2,2^{a}$ & $1,8^{a}$ \\
\hline T9 & $1,6^{\mathrm{a}}$ & $1,7^{a}$ & $2,2^{a}$ & $1,6^{a}$ & $2,3^{\dot{a}}$ & $1,9^{a}$ \\
\hline $\mathrm{T} 10$ & $1,4^{a}$ & $1,4^{a}$ & $2,2^{a}$ & $1,8^{a}$ & $2,3^{a}$ & $1,7^{a}$ \\
\hline Média & 1,65 & 1,61 & 2,16 & 1,78 & 2,24 & 1,79 \\
\hline C.V. ( $(\%)$ & & & & & & \\
\hline
\end{tabular}

Médias seguidas da mesma letra não diferem entre si pelo Teste de Duncan $(P<0,05)$.

1- Seqüências culturais 1,2 e 3

2- Seqüências culturais 4 e 5

3- Seqüências culturais 6 e 7 
ção das épocas de amostragem do solo, para as profundidades de 0-20 e 20-40 cm, após 4 anos de condução de sucessões culturais, envolvendo gramíneas e leguminosas.

Analisando os dados da Tabela 3 , podemos observar que os teores de matéria orgânica nas profundidades de 0-20 e 20-40 cm não apresentaram diferenças significativas entre os tratamentos estudados (seqüências culturais 1, 2 e 3) durante a $2 \mathfrak{a}$ amostragem. Detectou-se que os teores de matéria orgânica na profundidade de $0-20 \mathrm{~cm}$, para todos os tratamentos estudados na 2 a amostragem (envolvendo as três primeiras seqüências culturais), foram inferiores aos encontrados no início do presente trabalho (Tabela 2). Este fato pode ser atribuido à ação da mobilização e do cultivo do solo que incrementam a oxidação da matéria orgânica,promovendo decréscimos nos teores desse componente na camada superficial. Segundo RUSSEL (1973), as culturas que deixam insuficientes quantidades de matéria orgânica, aliadas às mobilizações do solo que incrementam a aeração e a decom posição, reduzem o conteúdo de matéria orgânica.

Pelo exposto, e com base nos dados obtidos de matéria orgânica para a profundidade de 0-20 cm, referentes à 2a amostragem, observou-se a não ocorrência de efeitos positivos das sucessões culturais de número 1, 2 e 3, sobre - incremento desta importante característica química do solo no período estudado. 
No entanto, os teores de matéria orgânica na camada subsuperficial (20-40 cm) foram superiores aos obtidos quando da implantação do presente experimento (Tabela 2). o maior retorno de palha e raízes, oriundas das seqüências culturais de $n \underline{0} 1,2$ e 3 , durante a primeira fase experimental, é um dos aspectos que pode explicar essa tendência, além da menor mobilização do solo e atividade microbiana na profundidade de 20-40 cm. De qualquer forma, observou-se um acréscimo nos teores de matéria orgânica na profundidade de 20-40 cm, de 1,2\% no início do presente experimento (Tabela 2) para 1,6\% em média na 2 a amostragem (Tabela 3 ).

$$
\text { Os resultados obtidos de matéria orgânica }
$$

para a 3a amostragem apontam, em geral, um aumento no conteúdo de matéria orgânica na profundidade de 0-20 cm,em relação aos teores obtidos nas amostragens de $n \underline{0} 1$ (Tabela 2) e 2 (Tabela 3). Esse acréscimo no conteúdo de matéria orgânica da amostragem de $n \underline{0} 2$ para de $n \underline{0} 3$ foi de 0,5 \% em média. Este fato deve-se ao maior aporte de restos culturais fornecidos através das cinco primeiras seqüências culturais. Deve-se destacar, ainda, que os resultados obtidos na 3 ạ amostragem foram muito uniformes entre os tratamentos estudados; por consegüinte, não se detectaram diferenças significativas entre os tratamentos estudados.

Analisando os teores encontrados na profun didade de 20-40 cm, na amostragem de $n \cong 3$ (Tabela 3 ), observa-se que os valores de matéria orgânica são inferiores aos 
obtidos na camada superficial (0-20 cm) da mesma amostragem; a única exceção ocorreu no tratamento T2. Os valores de matéria orgânica obtidos na amostragem de $n$ ㅇ 3 , não apresen taram diferenças significativas entre tratamentos, oscilando de 1,5 (T1) e $2,2 \%$ (T2).

Considerando os dados obtidos na última seqüência de culturas ( 4 a amostragem), pode-se observar na Tabela 3, que não existem diferenças nos teores de matéria orgânica entre os tratamentos estudados para as duas profundidades. Com relação à profundidade de 0-20 cm, verifi ca-se na Tabela 3 que o conteúdo de matéria orgânica entre - início da implantação das seqüências culturais (Tabela 2) e o término (Tabela 3) proporcionou um incremento em média de $0,2 \%$, alcançando maiores valores nos tratamentos T3, T5, T6, T9 e T10, que atingiram 0,3\% de acréscimo.

No entanto, pode-se observar, para a profundidade de 20-40 cm, aumentos em média na ordem de 0,6\% no teor de matéria orgânica, em relação aos dados obtidos na 1a amostragem (Tabela 2), durante a condução das sequiências culturais, atingindo $0,7 \%$ de diferença nos tratamentos T3 e T9.

0 menor incremento no teor de matéria orgâ nica para a camada de 0-20 cm pode estar diretamente relacionado ao efeito da incorporação e decomposição das leguminosas nas sucessões de número 1 a 3 , bem como a incorpo ração da ervilhaca na sucessão 6. Com o processo de decom - 
posição dessas culturas, pode ter ocorrido um maior fornecimento de nitrogênio por parte das leguminosas ao solo, contribuindo, assim, para uma rápida degradação dos restos culturais de ervas-daninhas e de gramíneas (que se apresentam com alta relação C/N) pelos microorganismos (LASSUS, 1990 ; DUCHAUFOR, 1979; MINHONI et alii, 1990; RUSSEL, 1963). Em outras palavras, como as leguminosas contribuem para uma maior atividade microbiana, promovem uma rápida decomposição da matéria orgânica. Com estes microorganismos atuam mais na camada superficial, justifica-se o menor teor de matéria orgânica na profundidade de 0-20 cm, e maior na de 20-40 cm.

$$
\text { Os resultados obtidos estão de acordo com }
$$
aqueles apresentados por WUTKE \& ALVAREZ (1968) e por SHIHCHUNG \& CHIN-CHEN (1970), que também não encontraram efeitos significativos da adubação verde e/ou incorporação de restos culturais nos teores de matéria orgânica do solo, levando a supor que em solos que estejam no seu nível de equilíbrio para as condições que são cultivados, principalmente em se tratando de solos de textura argilosa, pouco ou nada adianta aplicar resíduos vegetais de gramíneas e/ou leguminosas se o fim visadó tão somente elevar estes teores. No entanto,em solos de textura arenosa, o comportamento da interação gramínea-leguminosa em relação ao aumento nos teores de matéria orgânica pode demonstrar aumentos significativos (BAVER, 1972). 


\subsubsection{Potássio trocável}

Os teores de potássio trocável na 2 a tragem (Tabela 4) foram superiores aos obtidos antes da implantação das seqüências culturais, em ambas as profundidades (Tabela 2). Observa-se na Tabela 4 que o potássio trocável apresentou maiores teores na camada superficial (0-20 cm), em relação à subsuperficial (20-40 cm), em todos os tratamentos analisados.

Com base nos dados obtidos para a $2 \underline{a}$ amostragem (Tabela 4), denota-se a existência de diferenças significativas nos teores de potássio trocável somente na profundidade de 0-20 cm. Os tratamentos T5, T8 e T7 apresentaram os maiores teores de potássio trocável.

No geral, os teores de potássio trocável na camada superficial $(0-20 \mathrm{~cm})$ oscilaram desde o nível médio $\left(0,16\right.$ a $\left.0,30 \mathrm{meq} / 100 \mathrm{~cm}^{3}\right)$ até o nível alto $(0,31$ a 0,60 meq/100 $\mathrm{cm}^{3}$ ), conforme critérios estabelecidos por RAIJ et alii (1985). Na profundidade de 20-40 cm, os teores de potássio trocável variaram de baixo a médio. Observou-se também que na 2 ạ amostragem não ocorreram diferenças signifi cativas entre os tratamentos estudados na profundidade de 20-40 cm. Estes resultados estão de acordo com aqueles obtidos por CAMARGO et alii (1962), que também não verifica ram efeitos significativos da adubação verde nos teores de potássio trocável em Terra Roxa e no Latossolo Vermelho Amarelo. 
Tabela 4. Potássio Trocável obtido durante a condução das dife rentes seqüências culturais.

\begin{tabular}{|c|c|c|c|c|c|c|}
\hline \multirow{4}{*}{$\begin{array}{l}\text { Tratamento } \\
\text { T1 }\end{array}$} & \multicolumn{4}{|c|}{ Potássio trocável $\left(\mathrm{meq} / 100 \mathrm{~cm}^{3}\right)$} & \multirow{2}{*}{\multicolumn{2}{|c|}{$\begin{array}{c}4 \text { a } \text { Amostragem }{ }^{3} \\
\text { Profundidade }\end{array}$}} \\
\hline & \multicolumn{2}{|c|}{$\begin{array}{c}2 \underline{a} \text { Amostragem } \\
\text { Profundidade }\end{array}$} & \multicolumn{2}{|c|}{$\begin{array}{l}3 \text { a Amostragem }{ }^{2} \\
\text { Profundidade }\end{array}$} & & \\
\hline & \multicolumn{2}{|c|}{$\begin{array}{c}0-20 \underset{(\mathrm{cm})}{20-40} \\
.\end{array}$} & \multicolumn{2}{|c|}{$\begin{array}{c}0-20 \underset{(\mathrm{cm})}{20-40} \\
\mathrm{c}^{2}\end{array}$} & \multicolumn{2}{|c|}{$\begin{array}{c}0-20 \underset{(\mathrm{cm})}{20-40} \\
.\end{array}$} \\
\hline & $0,27^{\mathrm{C}}$ & $0,20^{\mathrm{a}}$ & $0,23^{a}$ & $0,08^{a}$ & $0,29^{\mathrm{a}}$ & $0,14^{\mathrm{a}}$ \\
\hline $\mathrm{T} 2$ & $0,24^{\mathrm{C}}$ & $0,15^{a}$ & $0,21^{a}$ & $0,09^{a}$ & $0,28^{a}$ & $0,14^{\mathrm{a}}$ \\
\hline T3 & $0,29^{\mathrm{C}}$ & $0,20^{\mathrm{a}}$ & $0,20^{a}$ & $0,08^{a}$ & $0,27^{a}$ & $0,14^{\mathrm{a}}$ \\
\hline $\mathrm{T} 4$ & $0,27^{C}$ & $0,18^{\mathrm{a}}$ & $0,18^{\mathrm{a}}$ & $0,08^{a}$ & $0,31^{\mathrm{a}}$ & $0,15^{\mathrm{a}}$ \\
\hline T5 & $0,45^{a}$ & $0,19^{a}$ & $0,18^{a}$ & $0,08^{a}$ & $0,27^{\mathrm{a}}$ & $0,14^{\mathrm{a}}$ \\
\hline T6 & $0,33^{\mathrm{bc}}$ & $0,20^{a}$ & $0,20^{a}$ & $0,09^{a}$ & $0,30^{a}$ & $0,16^{\mathrm{a}}$ \\
\hline T7 & $0,40^{\mathrm{ab}}$ & $0,21^{\mathrm{a}}$ & $0,18^{\mathrm{a}}$ & $0,10^{\mathrm{a}}$ & $0,30^{\mathrm{a}}$ & $0,18^{\mathrm{a}}$ \\
\hline $\mathrm{T} 8$ & $0,45^{a}$ & $0,14^{a}$ & $0,21^{a}$ & $0,07^{a}$ & $0,32^{\mathrm{a}}$ & $0,19^{a}$ \\
\hline T9 & $0,30^{\mathrm{C}}$ & $0,14^{\mathrm{a}}$ & $0,19^{\mathrm{a}}$ & $0,08^{\mathrm{a}}$ & $0,29^{a}$ & $0,18^{a}$ \\
\hline T10 & $0,30^{\mathrm{C}}$ & $0,11^{a}$ & $0,17^{a}$ & $0,10^{a}$ & $0,30^{\mathrm{a}}$ & $0,17^{a}$ \\
\hline Média & 0,33 & 0,17 & 0,20 & 0,09 & 0,29 & 0,16 \\
\hline C.V. ( $\left(\frac{\circ}{8}\right)$ & 22,8 & & 25 & & 23, & \\
\hline
\end{tabular}

Médias seguidas por letras distintas diferem entre si ao nível de significância $(P<0,05)$ pelo Teste de Duncan

1- Seqüências culturais 1,2 e 3

2- Seqüências culturais 4 e 5

3- Seqüências culturais 6 e 7 
Observa-se também que os teores de potássio trocável obtidos na terceira amostragem foram inferiores,em média, aos da 2 a amostragem nas duas profundidades analisadas. Ressalta-se também, que não foram detectadas diferen Ças entre tratamentos nas duas profundidades estudadas. Os teores de potássio na 3 a amostragem oscilaram entre 0,17 (T10) e 0,23 (T1) meq/100 $\mathrm{cm}^{3}$ na profundidade de 0-20 cm, e entre 0,07 (T8) a 0,10 (T7) meq/100 $\mathrm{cm}^{3}$ na de $20-40 \mathrm{~cm}$.

Esses teores de potássio trocável encontra dos na 3a amostragem variaram de médio $(0-20 \mathrm{~cm})$ a baixo (20-40 cm). No entanto, os valores encontrados na terceira amostragem continuaram, em média, superiores aos obtidos antes da instalação do experimento (Tabela 2). Este resul tado concorida com os obtidos por MASCARENHAS et alii (1977), os quais após incorporação de adubo verde em latossolo Roxo e Latossolo Vermelho Escuro-orto, verificaram aumentos no teor de potássio trocável. Em média, ocorreu uma redução no teor de potássio trocável entre a 2 a e $3 a$ amostragem, de 0,13 e 0,28 meq/100 $\mathrm{cm}^{3}$, respectivamente para as profundi dades de $0-20$ e $20-40 \mathrm{~cm}$.

$\mathrm{Na}$ Tabela 4 pode-se observar que os teores de potássio trocável encontrados na 4 a amostragem foram superiores, em média, aos da 3 ạ e 1ạ amostragem, porém, inferiores aos da 2 a amostragem, nas duas profundidades avaliadas. Cabe salientar, ainda, que os teores de potássio tro- 
cável na profundidade de 0-20 cm, oscilaram desde o nível médio (T1, T2, T3, T5, T6, T9 e T10) a alto (T4 e T8), enquanto na profundidade de $20-40 \mathrm{~cm}$, de baixo a médio.

Estatisticamente os teores de potássio trocável para as duas profundidades e nos diferentes tratamentos estudados, não diferiram entre si na amostragem de númeI0 4 .

\subsubsection{P-extraído (P-resina)}

Analisando-se os dados da Tabela 5, podemos observar diferenças significativas nos teores de fósforo extraído entre os tratamentos estudados (seqüências culturais de 1 a 3 ) para a 2 a amostragem, nas duas profundidades $(0-20$ e 20-40 cm). A concentração de fósforo, em média, foi maior na superfície. Contudo, os teores encontrados nas duas profundidades estudadas variaram de muito baixo a baixo, segundo os níveis críticos estabelecidos por RAIJ et alii (1985). Com exceção dos tratamentos T5, T7, T6 e T9, os demais apresentaram teores de fósforo extraído inferio res aos obtidos quando da implantação das seqüências culturais ( 1 a amostragem) para a profundidade de 0-20 cm. Constatou-se para os tratamentos T1 a T7 na profundidade de 20$40 \mathrm{~cm}$, teores de P-resina superiores aos da 1 a (Tabela 2). No geral, os valores de P-extraível obtidos para a profundidade de $20-40 \mathrm{~cm}$ foram muito baixos. 
Os resultados obtidos para o fósforo na 3 a amostragem (Tabela 5), nas duas profundidades estudadas, não apresentaram diferenças significativas entre tratamentos. Estes dados estão de acordo com os obtidos por MASCARENHAS et alii (1977), os quais não encontraram nenhuma influência da incorporação da adubação verde sobre o teor de fósforo, em Latossolo Roxo e Latossolo Vermelho Escuro-orto. Resul tados concordantes foram obtidos por VITTI et alii (1979) que, estudando a influência de alguns adubos verdes em Latossolo Vermelho Amarelo-fase arenosa, não denotaram nenhum aumento nos teores de fósforo solúvel, nas diferentes épocas de amostragens realizadas após a incorporação (três, seis, nove e doze meses). Estes resultados concordam, ainda, com os obtidos por CAMARGo et alii (1962), que não observaram efeitos significativos da adubação verde nos teores de fósforo.

Ressalta-se, ainda, que os dados encontrados na profundidade de 0-20 cm foram, em média, inferiores aos dados da 1a e 2a amostragens. Analisando-se os dados obtidos para a profundidade de 20-40 cm, verificou-se que em média, os teores de fósforo (P-resina) da 3 ạ amostragem continuaram superiores aos da $1 \underline{a}$ e iguais aos da $2 \underline{a}$ amostragem.

Com base nos dados da 4 a amostragem contidos na Tabela 5, observa-se que houve diferença significativa nos teores de fósforo extraído na profundidade de 0-20 cm. 
Tabela 5. Fósforo extraido (P-resina) obtido durante a condução das diferentes seqüências culturais.

\begin{tabular}{|c|c|c|c|c|c|c|}
\hline \multirow{4}{*}{$\begin{array}{l}\text { Profundidade } \\
\text { T1 }\end{array}$} & \multicolumn{6}{|c|}{ Fósforo extraído (P-resina) ug/ $\mathrm{cm}^{3}$} \\
\hline & \multirow{2}{*}{\multicolumn{2}{|c|}{$\begin{array}{l}2 \text { a Amostragem } \\
\text { Profundidade } \\
0-20 \quad 20-40 \\
(\mathrm{~cm})\end{array}$}} & \multirow{2}{*}{\multicolumn{2}{|c|}{$\begin{array}{c}3 \text { a Amostragem } \\
\text { Profundidade } \\
0-20 \quad 20-40 \\
\text { (cm) }\end{array}$}} & \multirow{2}{*}{\multicolumn{2}{|c|}{$\begin{array}{c}4 \text { a Amostragem } \\
3 \\
\text { Profundidade } \\
0-20 \quad 20-40 \\
(\mathrm{~cm})\end{array}$}} \\
\hline & & & & & & \\
\hline & $4^{e}$ & $5^{a b}$ & $3^{a}$ & $3^{a}$ & $10^{\mathrm{a}}$ & $3^{a}$ \\
\hline $\mathrm{T} 2$ & $6^{\mathrm{de}}$ & $5^{a b}$ & $5^{a}$ & $5^{a}$ & $4^{\mathrm{C}}$ & $4^{a}$ \\
\hline T3 & $5^{\mathrm{de}}$ & $5^{a b}$ & $4^{a}$ & $6^{a}$ & $8^{a b}$ & $4^{a}$ \\
\hline $\mathrm{T} 4$ & $6^{\mathrm{de}}$ & $6^{a}$ & $5^{a}$ & $6^{a}$ & $9^{a}$ & $5^{a}$ \\
\hline T5 & $16^{a}$ & $6^{a b}$ & $4^{\mathrm{a}}$ & $5^{a}$ & $3^{\mathrm{d}}$ & $4^{a}$ \\
\hline $\mathrm{T} 6$ & $8^{C}$ & $6^{a}$ & $3^{a}$ & $4^{\mathrm{a}}$ & $9^{a}$ & $4^{a}$ \\
\hline $\mathrm{T} 7$ & $11^{\mathrm{b}}$ & $5^{a b}$ & $5^{a}$ & $5^{a}$ & $8^{a b}$ & $5^{a}$ \\
\hline $\mathrm{T} 8$ & $6^{\mathrm{de}}$ & $4^{b}$ & $6^{a}$ & $5^{a}$ & $9^{a}$ & $5^{a}$ \\
\hline T9 & $8^{C}$ & $4^{b}$ & $3^{a}$ & $4^{a}$ & $8^{a b}$ & $5^{a}$ \\
\hline $\mathrm{T} 10$ & $6^{\mathrm{cd}}$ & $2^{C}$ & $3^{a}$ & $6^{a}$ & $7^{b}$ & $5^{a}$ \\
\hline Média & 7,6 & 4,9 & 4,1 & 4,9 & 7,5 & 4,4 \\
\hline C.V. (8) & 15 & & & & 20 & 29 \\
\hline
\end{tabular}

Médias seguidas por letras distintas diferem entre si ao nível de significância $(P<0,05)$ pelo Teste de Duncan.

1- Seqüências culturais 1,2 e 3

2- Seqüências culturais 4 e 5

3- Seqüências culturais 6 e 7 
Os teores de fósforo extraído encontrados para os diferentes tratamentos na profundidade de 0-20 cm foram, em média, superiores aos obtidos para as amostragens de números 1 e 3 .No entanto, para a profundidade de $20-40 \mathrm{~cm}$, não se detectaram diferenças significativas entre os tramentos. Observa-se, ainda, na 4ạ amostragem, que os teores de fósforo para a profundidade de $20-40 \mathrm{~cm}$ foram inferiores aos da camada superficial $(0-20 \mathrm{~cm})$.

\subsubsection{Cálcio trocável}

Os teores de cálcio trocável verificados na 2a amostragem, nas profundidades de 0-20 e 20-40 cm (Tabela 6), não apresentaram diferenças signj.ficativas entre os tratamentos estudados. A concentração de cálcio na profundidade de 0-20 cm aumentou de 1,50 (Tabela 2) para um valor médio de 4,09 meq/100 $\mathrm{cm}^{3}$ (Tabela 6), enquanto na profundidade de 20-40 cm observou-se um aumento de 0,90 para um valor médio de $2,61 \mathrm{meq} / 100 \mathrm{~cm}^{3}$.

WUTKE \& ALVAREZ (1968) mencionam que as leguminosas são mais eficazes na extração de cátions bivalentes do solo (cálcio e magnésio), podendo ocorrer um agravamento nas deficiências desses cátions trocáveis se a leguminosa incorporada não liberar, para a cultura següinte, em tempo hábil, os nutrientes extraídos. Portanto, com base nas avaliações de campo e nos dados da Tabela 6, não se verificou esse efeito durante a condução das três primeiras seqüências culturais. 
Tabela 6. Cálcio trocável do solo determinado nas diferentes seqüências culturais.

\begin{tabular}{|c|c|c|c|c|c|c|}
\hline \multirow{5}{*}{$\begin{array}{c}\text { Tratamento } \\
\text { T1 }\end{array}$} & \multicolumn{4}{|c|}{ Cálcio Trocável (meq/100 cm 3) } & \\
\hline & \multirow{2}{*}{\multicolumn{2}{|c|}{$\begin{array}{c}2 \text { a Amostragem }{ }^{1} \\
\text { Profundidade }\end{array}$}} & \multirow{2}{*}{\multicolumn{2}{|c|}{$\begin{array}{c}\text { 3a Amostragem }{ }^{2} \\
\text { Profundidade }\end{array}$}} & & \\
\hline & & & & & & \\
\hline & \multicolumn{2}{|c|}{$(\mathrm{cm})$} & \multicolumn{2}{|c|}{$(\mathrm{cm})$} & \multicolumn{2}{|c|}{$\begin{array}{l}\text { 4a Amostragem } \\
\text { Profundidade } \\
0-20 \quad 20-40 \\
(\mathrm{~cm})\end{array}$} \\
\hline & 3,93 & 1,44 & 3,27 & 1,39 & 3,34 & 2,53 \\
\hline $\mathrm{T} 2$ & 4,27 & 2,87 & 3,26 & 1,60 & 3,37 & 2,94 \\
\hline T3 & 3,76 & 2,32 & 3,39 & 1,54 & 3,35 & 2,87 \\
\hline $\mathrm{T} 4$ & 3,29 & 1,71 & 3,10 & 1,73 & 3,15 & 3,12 \\
\hline T5 & 4,54 & 3,77 & 3,21 & 1,55 & 3,52 & 3,27 \\
\hline T6 & 4,22 & 2,34 & 3,02 & 1,59 & 3,43 & 3,08 \\
\hline T7 & 3,94 & 2,32 & 3,20 & 1,84 & 3,01 & 2,63 \\
\hline T8 & 3,77 & 3,27 & 3,19 & 1,51 & 3,56 & 2,80 \\
\hline T9 & 4,66 & 2,84 & 3,11 & 1,21 & 3,54 & 2,92 \\
\hline T10 & 4,54 & 3,19 & 3,59 & 1,94 & 3,25 & 2,60 \\
\hline Média & 4,09 & 2,61 & 3,23 & 1,59 & 3,35 & 2,88 \\
\hline C.V. (\%) & & & & & & \\
\hline
\end{tabular}

Médias seguidas da mesma letra não diferem entre si pelo Teste de Duncan $(\mathrm{P}<0,05)$.

1- Seqüências culturais 1,2 e 3

2- Seqüências culturais 4 e 5

3- Seqüências culturais 6 e 7 
Com relação ao cálcio trocável (Tabela 6) da 3ạ amostragem, não se observou variação significativa do seu teor entre as seqüências culturais e profundidades estudadas. Esses dados obtidos são concordantes com CAMARGo et alii (1962), os quais estudaram a influência da adubação verde nas características químicas de uma Terra Roxa e de um Latossolo Vermelho Amarelo, e não denotaram efeitos significativos nos teores de óxido de cálcio, após 5 meses da realização dessa prática agrícola.

Verifica-se, ainda, na Tabela 6, redução no teor de cálcio trocável entre 2 a e $3 a$ amostragens que, em média, foi na ordem de 0,86 e $1,02 \mathrm{meq} / 100 \mathrm{~cm}^{3}$, respectivamente para as profundidades de 0-20 e 20-40 cm. Esse efeito, provavelmente, pode estar relacionado com as observações já abordadas anteriormente no trabalho de UUTKE \& ALVARES (1968). No geral, os valores obtidos durante a 3 a amostragem, tanto para a profundidade de 0-20 quanto para a de $20-40$ cm,foram superiores aos da $1 \underline{a}$ amostragem (Tabela 2).

Analisando os dados de cálcio trocável na 4 a amostragem (Tabela 6), observa-se que não houve diferenças significativas entre os tratamentos estudados. Os teores de cálcio trocável na última amostragem apresentaram-se,em média, superiores aos da 1 a amostragem.

De maneira geral, com relação aos dados da 4a amostragem, em particular na profundidade de 20-40 cm, 
observou-se um incremento de cálcio trocável ao término da última seqüência cultural em todos os tratamentos, cuja concentração se elevou de 0,90 (Tabela 2) a 2,88 meq/100 c 3 ( Tabela 6).

Os resultados obtidos na $4 \stackrel{a}{a}$ amostragem para os teores de cálcio trocável nas duas profundidades anali sadas (0-20 e 20-40 cm), em relação aos dados iniciais ( Tabela 2), apontam um incremento de 1,85 e 1,98 meq/100 $\mathrm{cm}^{3}$ na concentração de cálcio, na camada superficial (0-20 cm) e subsuperficial $(20-40 \mathrm{~cm})$. O enriquecimento de cálcio nas camadas subsuperficiais assegura um maior desenvolvimento do sistema radicular e da biomassa vegetal. Aumentando-se o crescimento do sistema radicular, ocorre maior aquisição de água e nutrientes em profundidade, e por consegüinte, maior produção de matéria orgânica (MEDEIROS, 1985).

\subsubsection{Magnésio trocável}

O conteúdo de magnésio trocável das áreas sob as diferentes seqüências culturais estudadas e em diferentes profundidades e épocas encontra-se na Tabela 7. Comparando-se os teores de magnésio trocável da 2 a amostragem (Tabela 7 ) com os da 1a (Tabela 2), observa-se maior concentração desse elemento nas duas profundidades, em relação aos dados iniciais. o teor de magnésio trocável na profundidade de $0-20 \mathrm{~cm}$ aumentou em média, de 0,50 (Tabela 2) para 1,62 meq/100 $\mathrm{cm}^{3}$ (Tabela 7). Porém, não se consta - 
Tabela 7. Magnésio trocável do solo determinado durante a dura ção das seqüências culturais.

\begin{tabular}{|c|c|c|c|c|c|c|}
\hline \multirow{4}{*}{$\begin{array}{c}\text { Tratamento } \\
\text { T1 }\end{array}$} & \multirow{2}{*}{\multicolumn{4}{|c|}{\begin{tabular}{cc}
\multicolumn{2}{c}{ Magnésio Trocável (meq/100 $\mathrm{cm}^{3}$ ) } \\
$\begin{array}{cc}\text { 2a Amostragem } & \\
\text { Profundidade } & \text { 3a Amostragem }\end{array}$ \\
\end{tabular}}} & \multirow{2}{*}{\multicolumn{2}{|c|}{$\begin{array}{c}4 \text { a Amostragem } \\
\text { Profundidade }\end{array}$}} \\
\hline & & & & & & \\
\hline & \multicolumn{2}{|c|}{$0-20(\mathrm{~cm})^{20-40}$} & \multicolumn{2}{|c|}{$0-20 \operatorname{(cm)}^{20-40}$} & \multicolumn{2}{|c|}{$0-20(\mathrm{~cm})^{20-40}$} \\
\hline & $1,63^{a}$ & $0,90^{a}$ & $1,79^{a}$ & $0,90^{a}$ & $2,07^{a}$ & $1,11^{b}$ \\
\hline $\mathrm{T} 2$ & $1,71^{a}$ & $1,35^{a}$ & $1,81^{a}$ & $0,91^{a}$ & $1,95^{a}$ & $1,14^{b}$ \\
\hline T3 & $1,42^{a}$ & $1,04^{a}$ & $1,80^{a}$ & $0,88^{a}$ & $1,85^{a}$ & $1,85^{b}$ \\
\hline $\mathrm{T} 4$ & $1,81^{a}$ & $0,70^{a}$ & $1,76^{\mathrm{a}}$ & $0,97^{a}$ & $1,72^{a}$ & $1,24^{b}$ \\
\hline T5 & $1,43^{a}$ & $1,42^{a}$ & $1,82^{a}$ & $0,93^{a}$ & $1,88^{a}$ & $1,14^{b}$ \\
\hline $\mathrm{T} 6$ & $1,68 \mathrm{a}$ & $1,18^{a}$ & $1,73^{a}$ & $0,98^{a}$ & $2,03^{a}$ & $1,28^{b}$ \\
\hline $\mathrm{T} 7$ & $1,70^{\mathrm{a}}$ & $1,13^{a}$ & $1,78^{a}$ & $1,07^{a}$ & $1,76^{\mathrm{a}}$ & $1,09^{b}$ \\
\hline T8 & $1,62^{a}$ & $1,17^{\mathrm{a}}$ & $1,78^{\mathrm{a}}$ & $0,93^{\mathrm{a}}$ & $1,93^{a}$ & $1,10^{\mathrm{b}}$ \\
\hline $\mathrm{T} 9$ & $1,49 a$ & $0,94^{a}$ & $1,71^{a}$ & $0,96^{a}$ & $1,90^{a}$ & $1,18^{\mathrm{b}}$ \\
\hline $\mathrm{T} 10$ & $1,71^{\mathrm{a}}$ & $1,19 a$ & $1,04^{\mathrm{b}}$ & $1,04^{a}$ & $1,78^{a}$ & $1,06^{b}$ \\
\hline Média & 1,62 & 1,10 & 1,70 & 0,96 & 1,89 & 1,22 \\
\hline C.V. ( $(\%)$ & 20 & & & & & 83 \\
\hline
\end{tabular}

Médias seguidas por letras distintas diferem entre si ao nível de significância indicado (Duncan 5\%) •

1- Seqüências culturais 1,2 e 3

2- Seqüências culturais 4 e 5

3- Seqüências culturais 6 e 7 
taram diferenças significativas na distribuição dos valores de magnésio trocável na profundidade de 0-20 cm, para os tratamentos estudados.

Entre a 1ạ e 2ạ amostragens, observou-se, em média, um incremento de 1,12 meq/100 $\mathrm{cm}^{3}$ de magnésio trocável para a profundidade de 0-20 cm. A concentração de magnésio trocável na profundidade de 0-20 cm oscilou de 1,42 (T3) a $1,81(\mathrm{~T} 4) \mathrm{meq} / 100 \mathrm{~cm}^{3}$.

Analisando-se os dados obtidos de magnésio trocável na profundidade de $20-40 \mathrm{~cm}$, constata-se um acrés cimo méuio na ordem de $0,80 \mathrm{meq} / 100 \mathrm{~cm}^{3}$, entre a 1a e 2a amostragens. Entre os tratamentos estudados não houve diferenças significativas, sendo a menor concentração do elemento no tratamento $T 4$ e a maior, no T5.

Os resultados obtidos diferem daqueles alcançados por VIEGAS et alii (1960a) e VITTI et alii(1979), os quais encontraram uma redução significativa nos teores de cálcio + magnésio do solo pela prática da adubação verde.

Quando se comparam os dados de magnésio tiovel da 3ạ e 4ạ amostragens para a profundidade de 0-20 cm, com os valores encontrados anteriormente ( 1 a e $2 \underline{a}$ amostragens), verifica-se que o teor desse elemento se apresentou ligeiramente superior para a $3 \underline{a}$ e $4 \underline{a}$ amostragens, em relação aos dados obtidos na 2a. A mesma tendência foi observada para a profundidade de 20-40 cm, sendo a 3a amostragem, em média, a única exceção. 
Todavia, quando se comparam os teores obtidos de magnésio trocável da 3 a e 4 a amostragens (Tabela 7) com os obtidos na 1 a avaliação (Tabela 2), observa-se para ambas as profundidades durante a condução do presente ensaio, um incremento significativo no teor de magnésio,saindo de níveis baixo (menor que $0,40 \mathrm{meq} / 100 \mathrm{~cm}^{3}$ ) para alto (maior que $0,80 \mathrm{meq} / 100 \mathrm{~cm}^{3}$ ), conforme interpretação estabelecida por RAIJ et alii (1985).

Os resultados de magnésio trocável para a 3 a amostragem, na profundidade de 0-20 cm, não apresentaram diferenças significativas entre os diferentes tratamentos estudados. Mas, para a profundidade $20-40 \mathrm{~cm}$, verificou-se que o tratamento T3, superou os demais pelo teste de Duncan a $5 \%$.

Comparados ao teor inicial, os valores encontrados refletiram um considerável acréscimo de magnésio trocável, para todos os tratamentos estudados, com o decorrer do tempo. Porém, deve-se destacar que esse efeito está diretamente relacionado com o formecimento de magnésio através do calcário dolomítico (MARTIN \& WARSMAN, 1940 e 1941 ; BROUNING \& MILAN, 1944) e, indiretamente, pela atuação das seqüencias culturais na reciclagem desse elemento, reduzindo as suas perdas por lixiviação, tendo em vista que o magnédio é mais móvel no solo do que o cálcio. 
60.

\subsection{6. $\mathrm{pH}$ em $\mathrm{H}_{2} \mathrm{O}$ e em $\mathrm{CaCl}_{2}$}

A análise estatística efetuada para os valores de $\mathrm{pH}$ em $\mathrm{H}_{2} \mathrm{O}$ e em $\mathrm{CaCl}_{2}$ revelou que não houve diferença significativa entre os tratamentos estudados (Tabelas para a 2a e 4a amostragens, na profundidade de 0-20 cm. No entanto, observaram-se diferenças significativas para o pH em $\mathrm{CaCl}_{2}$ na profundidade de $20-40 \mathrm{~cm}$, durante a 2 a amostra gem. Para o $\mathrm{pH}$ em H $\mathrm{H}_{2}$, não detectaram-se diferenças estatísticas na profundidade de $20-40 \mathrm{~cm}$ nas amostragens de números 2 e 4 .

Os valores de $\mathrm{pH}$ em água oscilaram entre 6,8 (T1, T3, T4 e T8) e 7,1 (T2, T6 e T9) na profundidade de 020 cm. Para a profundidade de $20-40$ cm essa variação foi de 6,2 (T4) a 6,7 (T2, T6, T7 e T10). Verifica-se na Tabela 9 que os valores de $\mathrm{pH}$ em $\mathrm{CaCl}_{2}$ variaram de 6,1 (T4 e T8) a 6,4 (T1 e T10) na profundidade de 0-20 cm. Já para a profunidade de 20-40 cm, essa oscilação foi de 4,3 (T4) a 5,9 ( T5 ) .

Verificando os resultados obtidos por diver sos autores, com os valores do índice de $\mathrm{pH}$ em $\mathrm{H}_{2} \mathrm{O}$ e em $\mathrm{CaCl}_{2}$ (para as duas profundidades na 2a amostragem) obtidos no presente trabalho, nota-se que eles são variáveis. Neste contexto, a tendência de comportamento dos resultados obtidos em função dos tratamentos, na 2 a amostragem, diferem daqueles obtidos por VIEGAS et alii (1960a), CAMARGO et alii 
Tabela 8. pH em $\mathrm{H}_{2} \mathrm{O}$ determinado durante a condução das diferen tes seqüencias culturais.

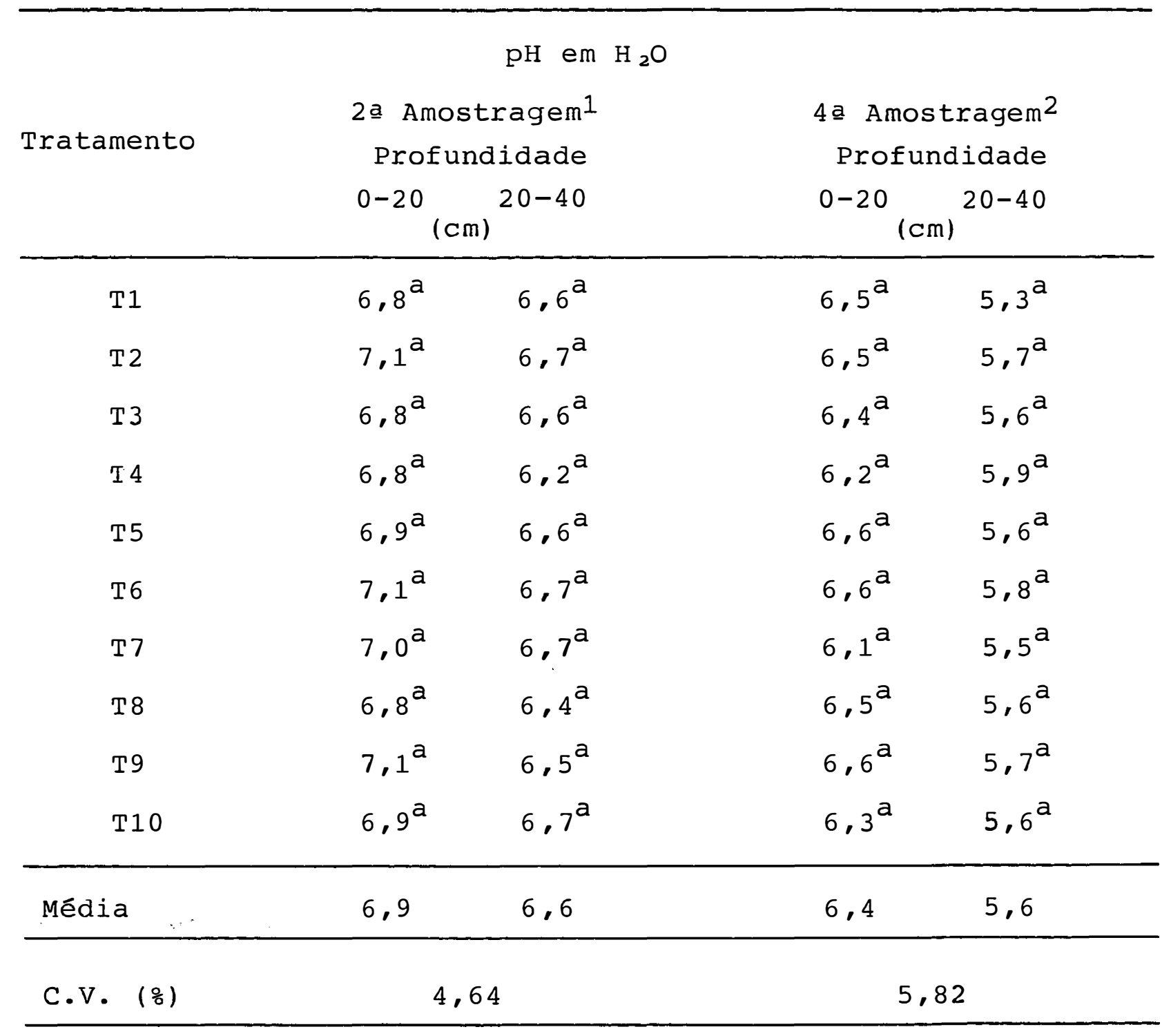

Médias seguidas da mesma letra não diferem entre si pelo Teste de Duncan $(P<0,05)$.

1- Seqüências culturais 1,2 e 3

2- Seqüências culturais 6 e 7 
Tabela 9. pH em $\mathrm{CaCl}_{2}$ determinado durante a condução das diferen tes seqüências culturais.

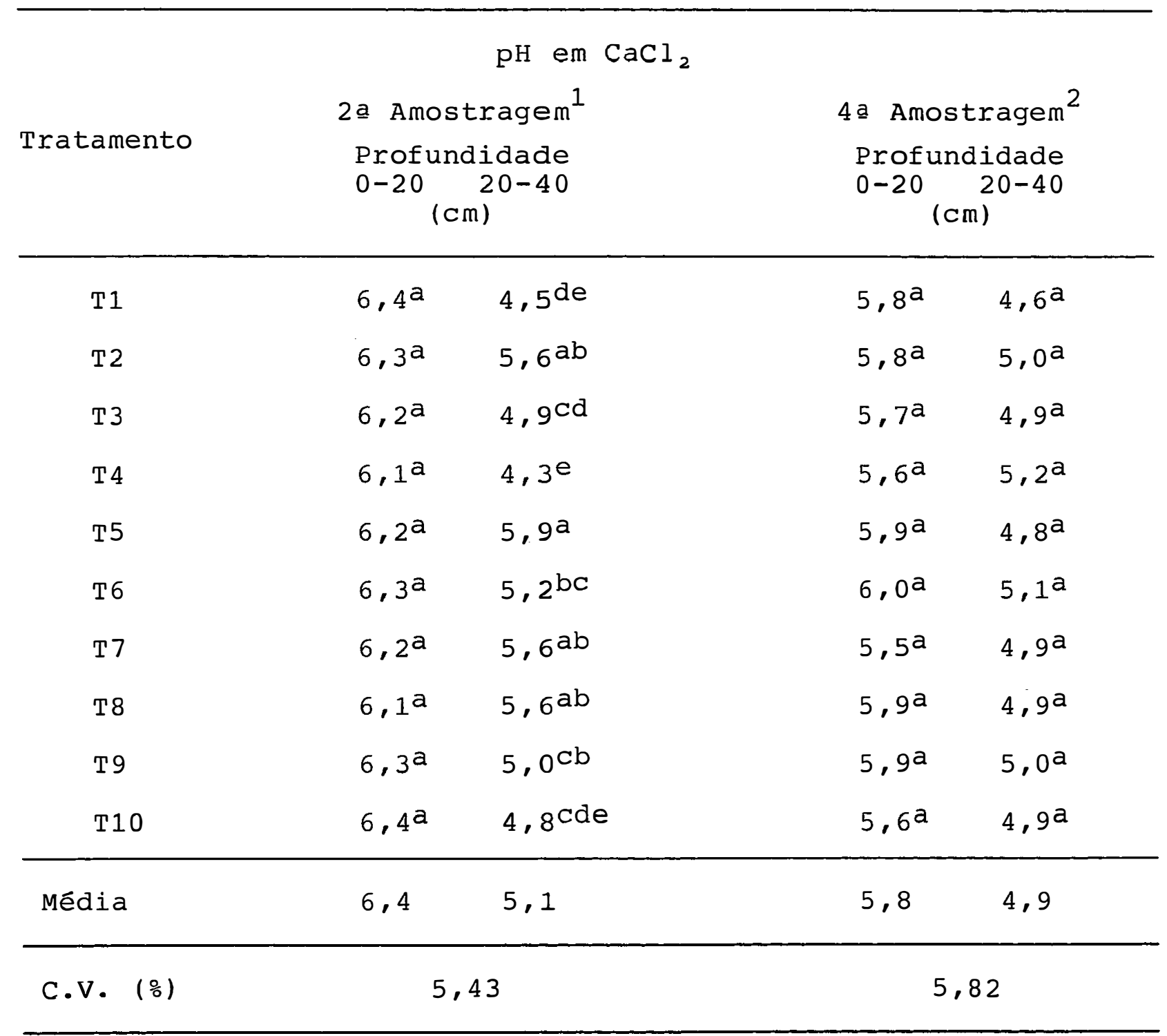

Médias seguidas por letras distintas diferem entre si ao nível de significância indicado (Duncan 5\%).

1 - Seqüências culturais 1,2 e 3

2- Sequêencias culturais 6 e 7 
(1962) e VITTI et alii (1971); os quais encontraram uma diminuição significativa no pH do solo, quando este recebia adubação verde e/ou incorporação de restos culturais.

$$
\text { Analisando os valores de } \mathrm{pH} \text { em } \mathrm{H}_{2} \mathrm{O} \text { e } \mathrm{CaCl}_{2}
$$

para a 4a amostragem, observa-se que, em média, o valor de $\mathrm{pH}$ em $\mathrm{H}_{2} \mathrm{O}(\mathrm{pH}=6,4)$ foi inferior aos obtidos na 2 a amostragem (Tabela 8), e superior ao valor encontrado para a 19 amostragem (Tabela 2) na profundidade de $0-20 \mathrm{~cm}$. 0 mesmo fato ocorreu para o pH em $\mathrm{CaCl}_{2}$ para a mesma profundidade estudada. Para a profundidade de $20-40 \mathrm{~cm}$, tanto o pH em $\mathrm{H}_{2} \mathrm{O}$ quanto $\circ \mathrm{pH}$ em $\mathrm{CaCl}_{2}$, apresentaram na 4 a amostragem valores inferiores aos obtidos para a 2 a amostragem e superiores aos da 1 a amostragem (Tabela 2).

Verificando os resultados obtidos na última amostragem ( 4 a amostragem), constata-se uma oscilação nos valores finais de $\mathrm{pH}$ em $\mathrm{H}_{2} \mathrm{O}$, para a profundidade de 0-20 cm, de 6,1 (T7) a 6,6 (T5, T6 e T9) e, para o pH em CaCl 2 , entre 5,5 (T7) e 6,0 (T6). Para a profundidade de 10-40 cm, os valores de $\mathrm{pH}$ em $\mathrm{H}_{2} \mathrm{O}$ e em $\mathrm{pH} \mathrm{CaCl}_{2}$ oscilaram de 5,3 (T1) a 5,9 (T4) e de 4,6 (T1) a 5,2 (T4) respectivamente. Devese destacar, ainda, que não foi verificada diferença significativa entre os tratamentos e profundidades estudadas para o $\mathrm{pH}$ em $\mathrm{H}_{2} \mathrm{O}$ e em $\mathrm{pH} \mathrm{CaCl}{ }_{2}$ na 4 a amostragem. 
64.

\subsubsection{Acidez potencial $(H+A l)$ e alumínio trocável} ( $A 1)$

Comparando-se os dados iniciais da acidez potencial (Tabela 2), com os resultados obtidos na 2a amostragem (Tabela 10), nota-se uma redução de 1,62 e 1,1 meq/100 $\mathrm{cm}^{3}$, respectivamente para as profundidades de $0-20$ e $20-40$ cm. Portanto, os valores de acidez potencial ( $H+A l)$ alcançados na 2a amostragem foram, em média, inferiores aos dados iniciais (Tabela 2), para as duas profundidades estudadas $(0-20$ e $20-40 \mathrm{~cm})$.

Não houve diferença estatística entre os tratamentos estudados na profundidade de $0-20 \mathrm{~cm}$, sendo que os teores de $\mathrm{H}+\mathrm{Al}$ variaram de 1,17 (Tg) a 1,60 (T4) meq/100 $\mathrm{cm}^{3}$. Os teores de $H+A l$ na profundidade de $20-40$ cm oscilaram de 1,73 (T5) a 3,80 (T4) meq/100 $\mathrm{cm}^{3}$, não ocorrendo, também,diferença estatística entre os tratamentos estudados. Deve-se destacar, ainda, que os teores de $H+A l$ obtidos na profundi dade de 0-20 cm foram inferiores aos encontrados na profun didade de $20-40 \mathrm{~cm}$.

Os teores de $H+A l$ alcançados na 4 a amostragem (Tabela 10) para a profundidade de $0-20 \mathrm{~cm}$, foram ligeiramente superiores aos da 2 a amostragem. Não ocorreram diferenças significativas para acidez potencial na profundidade de 0-20 e 20-40 cm na 4a amostragem, como pode ser observado na Tabela 10. Para a profundidade de $0-20 \mathrm{~cm}$, os teores de 
Tabela 10. H+Al (acidez potencial) determinado durante a condução das diferentes seqüência culturais.

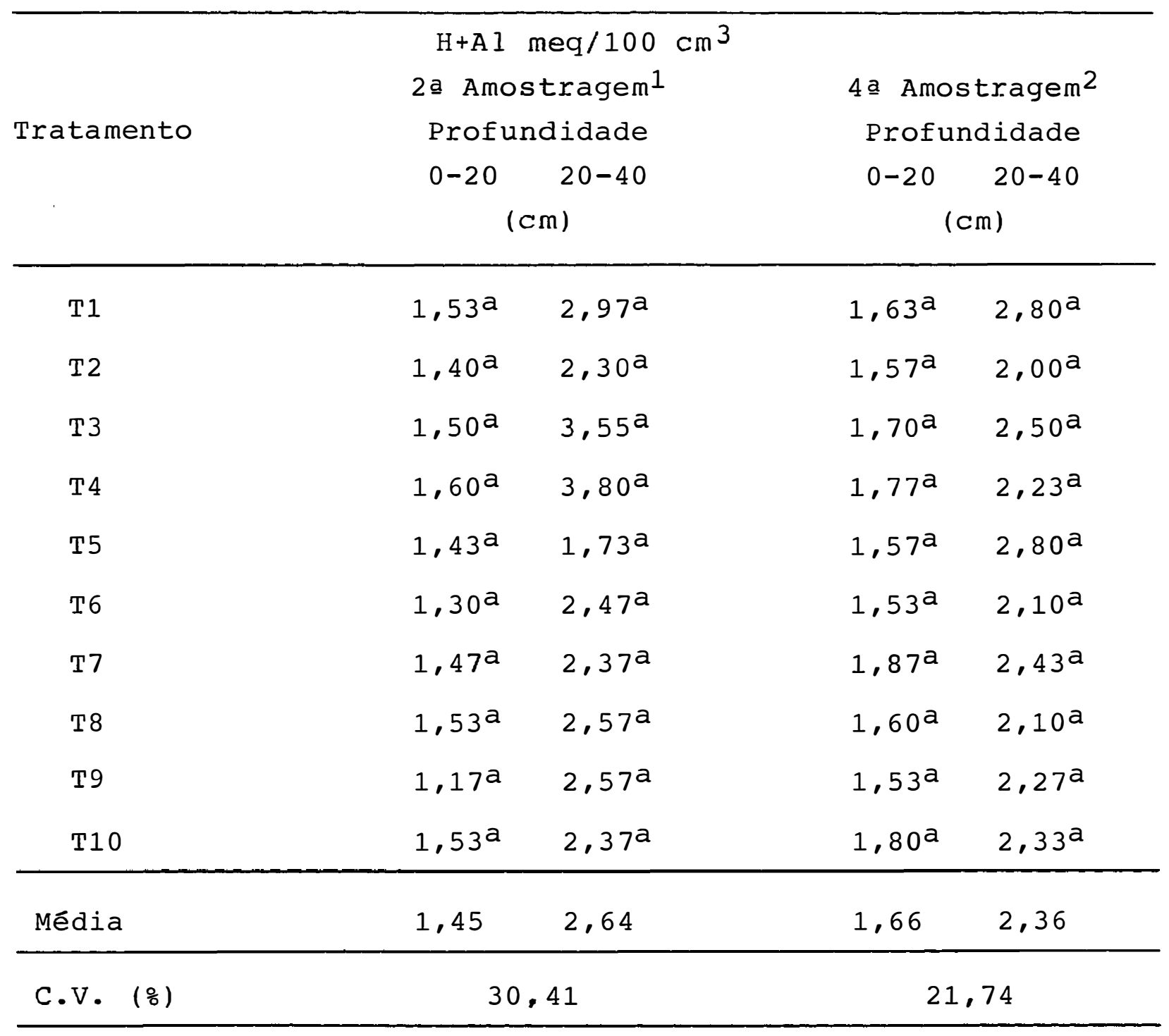

Médias seguidas da mesma letra não diferem entre si pelo Teste de Duncan $(\mathrm{P}<0,05)$. 
$\mathrm{H}+\mathrm{Al}$ oscilaram de 1,53 (T6 e T9) a $1,87(\mathrm{~T} 7) \mathrm{meq} / 100 \mathrm{~cm}^{3}$, sendo esses, em média, inferiores aos obtidos na 1 a amostragem (Tabela 2). Já na profundidade de $20-40 \mathrm{~cm}$, os valores de $H+A l$ oscilaram de 2,00 (T2) a 2,80 (T1 e T5) meq/cm ${ }^{3}$.

Os dados da Tabela 11 mostram os resultados referentes à concentração de alumínio trocável obtidos na 2a e 4a amostragens. Pode-se observar que na 2 a amostragem não ocorreram diferenças significativas entre os tratamen tos estudados para a profundidade de $0-20 \mathrm{~cm}$. No entanto, para a profundidade de $20-40 \mathrm{~cm}$, essas diferenças ocorreram. Comparando-se os dados obtidos na 2 a amostragem com os da 1a (Tabela 2), denota-se uma redução nos teores de alumínio trocável para as profundidades de 0-20 e 20-40 cm. Assim, verifica-se que os resultados alcançados na 2 a amostragem para ambas as profundidades analisadas (0-20 e 20-40 cm) são concordantes com os obtidos por VIEGAS et alii (1960a) e $\operatorname{COSTA}(1983)$.

Porém, resultados discordantes foram encontrados por VITTI et alii (1979), que encontraram um aumento significativo no teor de alumínio livre de um LatossoloVermelho Amarelo-fase arenosa como resultado da adubação verde.

Analisando os dados iniciais de alumínio trocável (Tabela 2), em relação aos teores encontrados na 2a amostragem (Tabela 11) para as profundidades de 0-20 e 20$40 \mathrm{~cm}$, verificaram-se reduções nos valores médios de alumínio (de 0,81 a 0,04 e de 2,44 a 0,14 meq/100 $\mathrm{cm}^{3}$, respecti- 
vamente para as profundidades de 0-20 e $20-40 \mathrm{~cm}$ ). Os teores de alumínio trocável obtidos na 2 a amostragem para as duas profundidades analisadas foram, em média, baixos (CATANI \& JACINTO, 1974).

Para os dados alcançados na 4 a amostragem (Tabela 11), verifica-se que não ocorreram diferenças significativas em relação ao alumínio trocável na profundidade de 0-20 cm. No entanto, observaram-se diferenças significativas entre os tratamentos estudados para a profundidade de 20-40 cm (Tabela 11). Os teores de alumínio trocável para a profundidade de 0-20 cm oscilaram de 0,02 (T6, T7, T8, T9 e T10) a 0,10 (T7) meq/100 $\mathrm{cm}^{3}$. Em média, o teor de alumínio trocável obtido na última amostragem $\left(0,03 \mathrm{meq} / 100 \mathrm{~cm}^{3}\right)$ foi inferior aos alcançados nas demais amostragens, para a profundidade de 0-20 cm. Já para a profundidade de 20-40 cm, os teores de Al-trocável variaram de 0,10 (T2, T4, T6, T8 e T9) a 0,47 (T1) meq/100 $\mathrm{cm}^{3}$. o valor médio encontrado de Al-trocável para a profundidade de $20-40 \mathrm{~cm}$ foi superior aos valores médios da 2 a amostragem, e inferiores aos da 1 a amostragem.

0 tipo de solo, a dose de calcário aplicad e o material vtilizado na incorporação provavelmente contribuiram para estas variações. Ressalta-se ainda, que o efeito das seqüencias culturais foi denotado de forma significativana camada subsuperficial (profundidade de 20-40 
Tabela 11. Alumínio trocável determinado durante a condução das diferentes seqüências culturais.

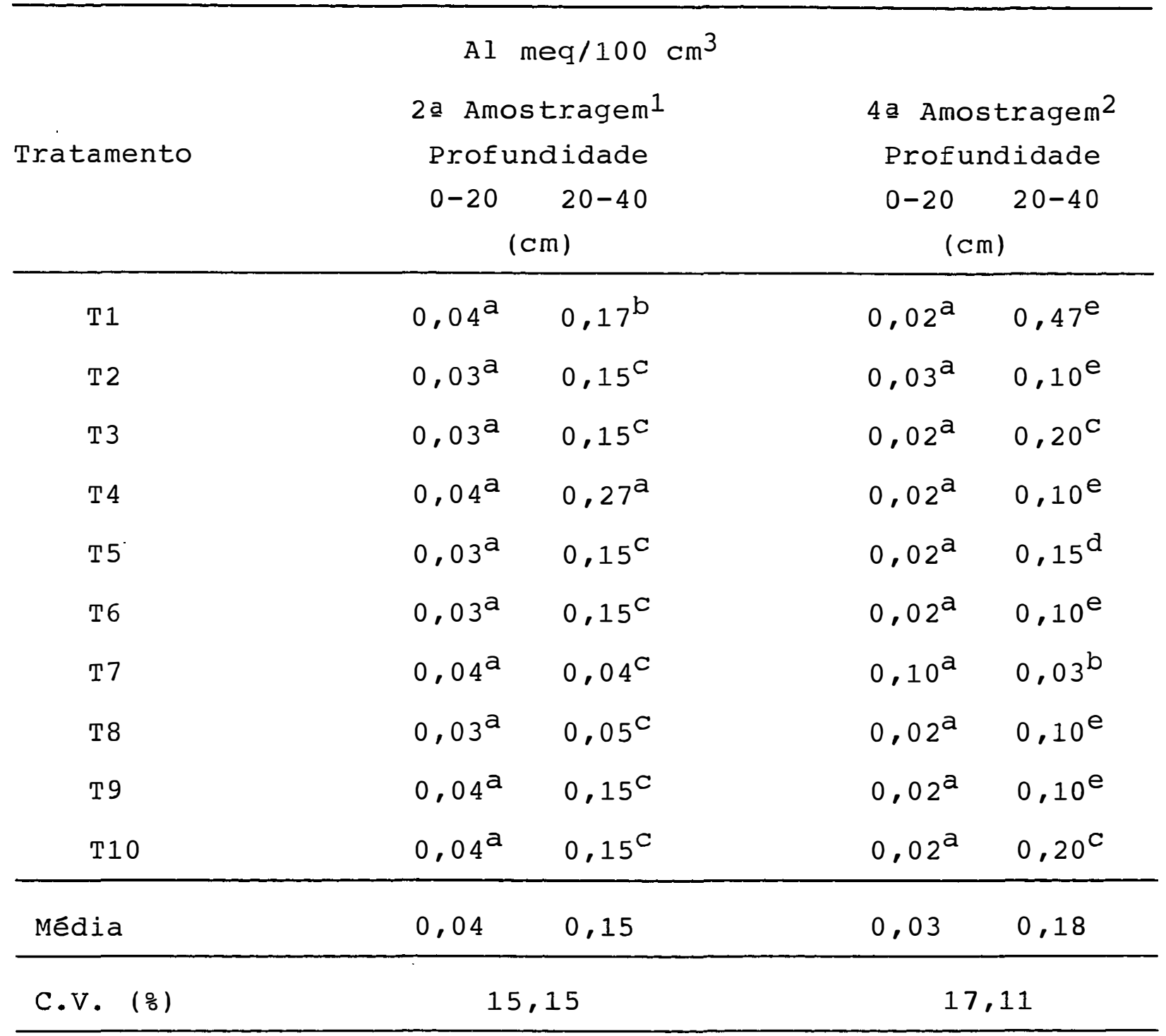

Médias seguidas por letras distintas diferem entre si ao nível de significância indicado (Duncan 5\%) •

1- Sequências culturais 1,2 e 3

2- Seqüências culturais 6 e 7 
cm). Porém, constatou-se após 4 anos de condução das seqüencias culturais, efeitos positivos sobre as concentrações de alumínio trocável para ambas as profundidades (0-20 e $20-40 \mathrm{~cm})$. 


\subsection{Efeito das seqüências culturais sobre as proprieda- des físicas}

0 manejo inadequado e incorreto dos solos agrícolas promove modificações na sua estrutura original, influenciando as següintes propriedades físicas: agregação, densidade e porosidade. Dessa forma, as culturas ou sistemas de culturas que apresentam efeitos positivos sobre a estrutura do solo podem deter o declínio da qualidade estrutural, como também promover a recuperação (reabilitação) de solos fisicamente degradados (DALLA ROSA, 1981).

\subsubsection{Efeito das seqüências culturais na estabili- dade de agregados estáveis em água.}

Os resultados observados quanto ao diâmetro médio ponderado (D.M.P.) dos agregados estáveis em água nas profundidades de 0-20 e 20-40 cm na 2a amostragem (Tabela 12) demonstraram que não ocorreu diferença estatística entre os tratamentos estudados.

Comparando os dados de diâmetro médio ponderado (D.M.P.) da $2 \underline{a}$ amostragem (Tabela 12) com os valores iniciais (Tabela 2), pode-se observar que os maiores aumentos de D.M.P. foram encontrados para os tratamentos T5 $(5,63 \mathrm{~mm})$ e $\operatorname{Tg}(5,62 \mathrm{~mm})$. De um modo geral, o valor médio do D.M.P. para todos os tratamentos avaliados na 2 a amostragem (Tabela 12) foi ligeiramente superior ao valor ini- 
Tabela 12. Efeito da seqüência de culturas na estabilidade de agregados estáveis em água.

\begin{tabular}{|c|c|c|c|c|c|c|}
\hline \multirow{4}{*}{$\begin{array}{l}\text { Trata- } \\
\text { mento }\end{array}$} & \multicolumn{6}{|c|}{ Diâmetro médio ponderado (mm) } \\
\hline & \multirow{2}{*}{\multicolumn{2}{|c|}{$\begin{array}{l}\text { 2a Amostragem } \\
\text { Profundidade }\end{array}$}} & \multirow{2}{*}{\multicolumn{2}{|c|}{$\begin{array}{l}3 \text { a Amostragem } \\
\text { Profundidade }\end{array}$}} & \multirow{2}{*}{\multicolumn{2}{|c|}{$\begin{array}{l}\text { 4a Amostragem }{ }^{3} \\
\text { Profundidade }\end{array}$}} \\
\hline & & & & & & \\
\hline & $0-20$ & $20-40$ & $0-20$ & $20-40$ & $0-20$ & $20-40$ \\
\hline T1 & $5,23^{a}$ & $5,08^{a}$ & $5,75^{a b}$ & $5,99^{a}$ & $5,89^{\text {bcd }}$ & $5,03^{d}$ \\
\hline $\mathrm{T} 2$ & $5,58^{a}$ & $5,38^{a}$ & $5,62^{a b c}$ & $5,15^{b}$ & $6,44^{a}$ & $5,45^{a b c d}$ \\
\hline T3 & $5,23^{a}$ & $5,55^{a}$ & $5,77^{\mathrm{ab}}$ & $4,79^{\mathrm{C}}$ & $6,09^{a b c}$ & $5,44^{\text {abcd }}$ \\
\hline T4 & $5,31^{a}$ & $4,70^{a}$ & $4,85^{a}$ & $5,26^{b}$ & $6,14^{a b}$ & $5,68^{a}$ \\
\hline T5 & $5,63^{a}$ & $5,59^{a}$ & $5,44^{b c}$ & $4,06^{d}$ & $5,67^{\text {bcd }}$ & $5,16^{\mathrm{bcd}}$ \\
\hline T6 & $5,33^{a}$ & $5,87^{a}$ & $3,98^{b}$ & $3,97^{d}$ & $5,43^{d}$ & $5,74^{a}$ \\
\hline $\mathrm{T} 7$ & $5,51^{a}$ & $5,51^{a}$ & $5,28^{\mathrm{cd}}$ & $4,52^{\mathrm{C}}$ & $5,42^{d}$ & $5,55^{a b c}$ \\
\hline T8 & $5,58^{a}$ & $5,25^{a}$ & 4,9 de & $4,11^{d}$ & $5,64^{\mathrm{cd}}$ & $5,63^{a b}$ \\
\hline T9 & $5,62^{a}$ & $5,38^{a}$ & $5,60^{a b c}$ & $5,46^{b}$ & $5,76^{\text {bcd }}$ & $5,59^{a b}$ \\
\hline T10 & $5,32^{a}$ & $4,92^{a}$ & $5,85^{a}$ & $5,35^{b}$ & $5,44^{d}$ & $5,08^{c d}$ \\
\hline Média & 5,38 & 5,32 & 5,31 & 4,88 & 5,79 & 5,44 \\
\hline C.V. \% & & & 4,13 & & 4,80 & \\
\hline
\end{tabular}

Médias seguidas por letras distintas diferem entre si ao nível de significância indicado (Duncan 5\%).

1. Seqüências culturais 1,2 e 3.

2. Seqüências culturais 4 e 5 .

3. Seqüências culturais 6 e 7 . 
cial (Tabela 2) para a camada de solo na profundidade de 0$20 \mathrm{~cm}$. Na profundidade de $20-40 \mathrm{~cm}$, observou-se um incre mento do D.M.P. para a maioria dos tratamentos em relação aos dados inciais; as exceções foram os tratamentos T4 e T10. Os resultados obtidos quanto à distribuição do D.M.P. para a profundidade de 20-40 cm não evidenciaram diferenças significativas entre os tratamentos estudados.

Este aumento no D.M.P. dos agregados está veis em água para a $2 \mathfrak{a}$ amostragem, pode estar provavelmente relacionado com o incremento no teor de matéria orgânica na profundidade de 20-40 cm (Tabela 3), caracterizando, dessa forma, o efeito positivo da consorciação gramínea-leguminosa sobre a agregação do solo dentro de um programa de sucessões culturais. Essa tendência de comportamento também foi denotada nos trabalhos de DALLA ROSA (1981) e MEDEIROS (1985) que encontraram efeitos positivos da interação gramínea-leguminosa, estimulando a formação de agregados estáveis em água.

Analisando os dados obtidos na 3 a amostragem, após cinco seqüências culturais (Tabela 12), observaram-se diferenças significativas entre os tratamentos estudados para as duas profundidades $(0-20$ e 20-40 c,). Os resíduos orgânicos das raízes e da parte aérea, associados à interação de gramíneas e leguminosas, além de atividade dos microorganismos do solo em estudo, promoveram maior estabili- 
dade de agregados estáveis para alguns tratamentos durante a 3 a amostragem.

$$
\text { Pode-se observar na Tabela } 12 \text { que o D.M.P. }
$$
dos agregados estáveis em água para a camada de 0-20 cm,oscilaram de 3,98 (T6) a 5,85 mm (T10). Os tratamentos T10, T3, T1 e T2, foram mais eficazes no aumento do D.M.P. dos agregados em relação aos dados da segunda amostragem. Segundo HÉNIN et alii (1976), o tipo de resî̉duo orgânico e os constituintes do húmus exercem influência direta sobre a estabilidade dos agregados. No que tange a camada de 20-40 cm, verificou-se uma variação de 3,97 (T6) a 5,99 mm (T1). Ressalta-se, ainda, que em média ocorreu uma redução no valor do D.M.P., quando comparados os valores obtidos na $3 \underline{a}$ amostragem com os da $1 \mathfrak{a}$ e $2 \underline{a}$ (profundidades ce 20-40 cm) amostragens.

A análise de variância dos dados obtidos quanto ao diâmetro médio ponderado (D.M.P.) contido na Tabela 12, nas profundidades estudadas, mostra diferenças es:tatísticas nas médias do D.M.P. dos tratamentos avaliados na última amostragem, após 4 (quatro) anos de cultivo. Os resultados observados na distribuição dos valores de D.M.P. para a 4 a amostragem, demonstraram efeito positivo das espécies vegetais estudadas sobre a agregação do solo.

$$
\text { Um aspecto importante a ressaltar é que a }
$$
melhoria na agregação do solo deve-se ao efeito do aporte 
de restos culturais e da atividade dos microorganismos que agem na decomposição dos resíduos (MARTIN \& WAKSMAN, 1940 e 1941). Portanto, resíduos orgânicos que tenham pouca influência na atividade microbiana no solo serão menos eficazes na agregação. Ressalta-se, contudo, que a mudança na vegetação causa um desequilíbrio no ecossistema e as qualidades intrínsecas da nova vegetação influenciarão nos processos físicos e químicos, como também nos biológicos do solo, modificando algumas características como matéria orgânica, complexo argilo-húmus e capacidade de troca de cátions (VUDOR, 1984; LASSUS, 1990; BAVER, 1968; DALLA ROSA, $1981)$

Os valores de D.M.P. na 4 a amostragem para a profundidade de 0-20 cm, oscilaram de 5,44 (T7) a 6,44 (T2). Com exceção do tratamento T10, os demais apresentaram aumento no D.M.P. em relação às amostragens de números 1, 2 e 3. Os maiores valores de diâmetro médio ponderado (D.M.P.) encontrados na última amostragem estão diretamente relacionados com o efeito de sete seqüencias culturais, favorecendo, dessa forma, a agregação do solo em estudo, pois, segundo DUCHAUFOR (1979) a constituição dos resíduos vegetais incorporados tem influência sobre as características físicas, químicas e biológicas do solo. Os resíduos orgânicos das raízes e da parte aérea, nas diferentes sucessões estudadas, atuaram como matéria-prima para a síntese microbiana 
de substâncias ligantes, sendo provavelmente um dos fatores que contribuiram para uma maior estabilidade de agregados ( VIDOR, 1984).

Observaram-se diferenças significativas entre os tratamentos analisados, para a profundidade de $20-40 \mathrm{~cm} .0$ diâmetro médio ponderado (D.M.P.) dos agregados estáveis em água oscilou de 5,03 (T1) a 5,74 mm (T6) na camada subsuperficial (20-40 cm). Em média, os D.M.P. encontrados para a 4 a amostragem foram superiores aos das demais amostragens. Em subsuperfície, os valores de D.M.P. foram menores em relação aos da camada superficial, sendo as exceções os tratamentos T6 e T7; este fato pode estar relacionado com o tipo de material que foi incorporado na subsuperfície, além do efeito do sistema radicular e atividade dos microorganismos. De qualquer forma, observou-se, ao longo do experimento, efeito na estabilidade dos agregados, tanto na camada superficial como na subsuperficial.

Segundo BALDISSERA (1985) a maior proporção de agregados, aiores que $4,76 \mathrm{~mm}$ nas parcelas com consorciação de gramíneas e leguminosas demonstra maior eficácia dessas culturas na agregação das partículas do solo. Neste sentido, espécies de gramíneas e leguminosas capazes de proporcionar maior cobertura, retorno de resíduos de melhor qualidade, abundante sistema radicular com produção de secreções de elevada capacidade agregante, como também a menor 
mobilização do solo, favorecem a agregação. Deve-se destacar, ainda, sobre este assunto, que os minerais de argila e os sesquióxidos de ferro e alumínio, tão comuns nos latossolos, associados a matéria orgânica (proveniente da decomposição de gramíneas e leguminosas, contribuem para a agre gação do solo, conforme menciona KIEHL (1979) e CosTA (1983).

Vários autores têm demonstrado uma correlação direta entre o teor de carbono orgânico e agregação, porém nem sempre se observa este efeito positivo. Assim, deve-se levar em conta o tipo de composto orgânico, pois materiais orgânicos que tenham pouca influência na atividade dos microorganismos do solo serão menos eficientes na agregação.

Além desses fatores, a calagem e os fertili zantes proporcionam crescimento rápido dos vegetais, contribuindo com maior produção de biomassa. O incremento na produção e no desenvolvimento vegetativo de raízes, caules e folhas, resultou no aumento da adição de matéria orgânica ao solo e, indiretamente, a adição de calcário e fertilizantes estimulou a atividade dos microorganismos do solo. Como conseqüência dessa interação, observa-se, na Tabela 12, um aumento significativo na estabilidade dos agregados do solo em estudo. 


\subsubsection{Efeito das seqüências culturais na densidade e porosidade do solo}

\subsubsection{Densidade do solo}

A análise de variância dos dados de densidade do solo, contidos nas Tabelas 13 e 14 , nas profundidades estudadas $(0-20$ e 20-40 cm), חão detectou diferenças signifi cativas para os tratamentos avaliados na última amostragem, valendo o mesmo resultado, para as amostragens intermediárias ( 2 a e 3a amostragens).

Analisando os dados de densidade do solo na profundidade de 0-20 cm, contidos na Tabela 13, observa- se que ocorreu uma ligeira redução nos valores de densidade do solo para os tratamentos T1, T2, T3, T4, T8, T9 e T10, em relação aos dados da 1 ạ amostragem $\left(1,31 \mathrm{~g} / 100 \mathrm{~cm}^{3}\right)$. Por outro lado, verificou-se um incremento na densidade do solo para os tratamentos T5, T6 e T7. 0 aumento na densidade do solo para estes tratamentos (T5, T6 e T7), pode estar provavelmente relacionado à compactação natural do solo. Os dados de densidade do solo obtidos para a camada superficial (0-20 cm) estão dentro da faixa de valores estabelecidos por BRADY (1979), ou seja, variam de 1,00 a 1,60 g/100 cm ${ }^{3}$ para solos com textura fina.

Com base nos dados de densidade do solo alcançados para a profundidade de 0-20 cm, verificou-se que 
78 .

Tabela 13 - Efeito da seqüência de culturas na densidade e porosidade do solo na profundidade de 0-20 cm ( 4 a amostragem)?

\begin{tabular}{|c|c|c|c|c|c|}
\hline \multirow{2}{*}{$\begin{array}{l}\text { Trata- } \\
\text { mento }\end{array}$} & \multirow{2}{*}{$\begin{array}{l}\text { Densidade } \\
\text { do solo } \\
\left(\mathrm{g} / \mathrm{cm}^{3}\right)\end{array}$} & \multicolumn{3}{|c|}{ Porosidade (\%) } & \multirow{2}{*}{ Ug \% } \\
\hline & & Macro & Micro & Total & \\
\hline T1 & $1,28^{\mathrm{a}}$ & $23,0^{a}$ & $23,3^{a}$ & 46,3 & 16,0 \\
\hline $\mathrm{T} 2$ & $1,27^{a}$ & $23,6^{a}$ & $25,5^{a}$ & 49,1 & 16,0 \\
\hline T3 & $1,24^{a}$ & $22,7^{a}$ & $22,4^{a}$ & 45,1 & 16,0 \\
\hline $\mathrm{T} 4$ & $1,24^{a}$ & $25,7^{a}$ & $23,3^{a}$ & 49,0 & 16,0 \\
\hline T5 & $1,33^{a}$ & $23,6^{\mathrm{a}}$ & $24,2^{a}$ & 47,8 & 16,0 \\
\hline T6 & $1,33^{a}$ & $17,8^{a}$ & $27,1^{a}$ & 44,9 & 16,0 \\
\hline $\mathrm{T} 7$ & $1,38^{a}$ & $20,0^{a}$ & $27,8^{a}$ & 47,8 & 16,0 \\
\hline T8 & $1,29^{a}$ & $22,7^{a}$ & $23,3^{a}$ & 46,0 & 16,0 \\
\hline Tg & $1,26^{\mathrm{a}}$ & $23,9^{a}$ & $22,1^{a}$ & 46,0 & 16,0 \\
\hline T10 & $1,26^{\mathrm{a}}$ & $23,3^{a}$ & $23,0^{a}$ & 46,3 & 16,0 \\
\hline C.V. (\%) & 4,46 & 14,33 & 6,87 & & \\
\hline
\end{tabular}

Médias seguidas da mesma letra não diferem entre si pelo Teste de Duncan ( $P$ 0,05).

1. Seqüências culturais 6 e 7 . 
79.

Tabela 14 - Efeito da seqüência de cultura na densidade 8 porosidade do solo, na profundidade de $20-40 \mathrm{~cm}$ ( 4 a amostragem $)^{1}$.

\begin{tabular}{|c|c|c|c|c|c|}
\hline \multirow{2}{*}{$\begin{array}{l}\text { Trata- } \\
\text { mento }\end{array}$} & \multirow{2}{*}{$\begin{array}{l}\text { Densidade } \\
\text { do solo } \\
\left(g / \mathrm{cm}^{3}\right)\end{array}$} & \multicolumn{3}{|c|}{ Porosidade (\%) } & \multirow{2}{*}{ \% } \\
\hline & & Macro & Micro & Total & \\
\hline T1 & $1,39^{a}$ & $13,0^{a}$ & $25,5^{a}$ & 38,5 & 17,0 \\
\hline $\mathrm{T} 2$ & $1,48^{\mathrm{a}}$ & $13,9^{\mathrm{a}}$ & $23,6^{a}$ & 37,5 & 17,0 \\
\hline T3 & $1,40^{\mathrm{a}}$ & $15,2^{a}$ & $24,9^{a}$ & 40,1 & 17,0 \\
\hline T4 & $1,37^{a}$ & $16,3^{\mathrm{a}}$ & $24,5^{a}$ & 40,8 & 17,0 \\
\hline T5 & $1,40^{a}$ & $14,6^{\mathrm{a}}$ & $26,7^{\mathrm{a}}$ & 41,3 & 17,0 \\
\hline T6 & $1,41^{a}$ & $15,1^{\mathrm{a}}$ & $25,8^{a}$ & 40,9 & 17,0 \\
\hline $\mathrm{T} 7$ & $1,40^{a}$ & $15,2^{a}$ & $26,4^{a}$ & 41,6 & 17,0 \\
\hline T8 & $1,37^{a}$ & $14,9^{a}$ & $25,6^{a}$ & 40,5 & 17,0 \\
\hline T9 & $1,42^{a}$ & $17,3^{a}$ & $25,5^{a}$ & 42,8 & 17,0 \\
\hline T10 & $1,37^{a}$ & $15,0^{a}$ & $26,4^{a}$ & 41,4 & 17,0 \\
\hline C.V. ( $(\%)$ & 4,46 & 14,33 & 6,87 & & \\
\hline
\end{tabular}

Médias seguidas da mesma letra não diferem entre si pelo Teste de Duncan ( $P$ 0,05).

1. Seqüências culturais 6 e 7 . 
nenhum dos tratamentos estudados apresentou diferenças entre si, com o passai do tempo. No entanto, constatou-se um decréscimo no valor médio final (4a amostragem) em relação aos dados iniciais ( 1 a amostragem). Assim, observou-se que as sucessões culturais, embora tenham proporcionado reduções na densidade do solo para a maioria dos tratamentos (T1, T2,T3, T4, T8, T9 e T10), não apresentaram diferenças significativas, quando se efetuou a análise estatística.

Essa tendência de comportamento foi também denotada por WUTKE \& ALVAREZ (1968) e RESCK \& PEREIRA (1970) que, estudando o efeito da incorporação de diferentes restos culturais ao solo, não encontraram diferenças significativas entre os tratamentos estudados com a densidade do solo. Contudo, deve-se ressaltar que UHLAND (1949) observou diferenças significativas na densidade do solo, com o cultivo de diferentes espécies de gramíneas, somente após 12 anos, quando o mesmo obteve uma redução de 1,31 à $1,00 \mathrm{~g} / 100 \mathrm{~cm}^{3}$ na densidade, para a profundidade de $0-15 \mathrm{~cm}$ em solo francosiltoso.

Analisando os dados da $4 \underline{a}$ amostragem contidos na Tabela 14, verifica-se que ocorreram reduções nos valores de densidade do solo para todos os tratamentos na profundidade de 20-40 cm, em relação aos dados da 1ạ amostragem (Tabela 2); porém, não ocorreram diferenças significativas entre os tratamentos estudados. Observando ainda, os dados da 
Tabela 14, denota-se um maior efeito das sucessões culturais na redução da densidade do solo para os tratamentos T4, T8, T10 e T1. No entanto, deve-se destacar que, em média,os valores de densidade do solo obtidos para a 4 a amostragem $\left(1,40 \mathrm{~g} / 100 \mathrm{~cm}^{3}\right)$ são inferiores aos da 1 a amostragem (1,51 $\left.\mathrm{g} / 100 \mathrm{~cm}^{3}\right)$.

As diferenças observadas para a densidade do solo, entre a 1a e $4 \underline{a}$ amostragens, deve-se provavelmente ao aporte de resíduos na camada subsuperficial, o que proporcionou um aumento do teor de matéria orgânica (Tabela3), melhorando a estrutura do solo. Ressalta-se, ainda, o efeito direto e indireto de outros atributos do solo na profundidade de 20-40 cm, tais como: atividade de microorganismos,pre-sença de cátions trocáveis, pH, etc. (KIEHL, 1979; COSTA, 1983; DALLA ROSA, 1981; CARPENEDO, 1985; MEDEIROS, 1985 \& BALDISSERA, 1985

\subsubsection{Porosidade do solo}

Os dados de porosidade total, macro e micro porosidade, apresentados nas Tabelas 13 e 14 , respectivamente para as profundidades de 0-20 e $20-40 \mathrm{~cm}$, não apresenta ram diferenças significativas entre os tratamentos e profun-

didades estudadas. Esses resultados são concordantes com os alcançados por RESCK \& PEREIRA (1979), que mencionam a não 
ocorrência de efeitos significativos da adubação verde e da incorporação de restos culturais na porosidade de um Latossolo Vermelha-Amarelo de textura argilosa.

Analisando os dados da 4 a amostragem em relação aos da 1 a amostragem, observou-se um maior incremento na macroporosidade na profundidade de 0-20 e 20-40 cm, respectivamente para os tratamentos T4 $(25,7 \%)$ e $\operatorname{Tg}(17,3 \%)$. 0 volume de poros totais para a profundidade de 0-20 cm variou de $44,9 \%$ ( T69 a 49,1\% (T2), enquanto para a camada de solo na profundidade de $20-40$ cm a variação foi de $37,5 \%$ ( T2) a $42,8 \%(\mathrm{~T})$.

Com a profundidade, verificou-se um decrés cimo da porosidade total e da macroporosidade, além do aumento da microporosidade, o que corresponde ao comportamento natural do solo. 
83.

\section{CONCLUSÕES}

A análise dos dados do presente trabalho,conduzido sob condições de campo, após quatro anos de seqüências culturais, levaram as seguintes conclusões:

1. Não houve efeito das seqüências culturais em nenhuma das profundidades estudadas, no teor de matéria orgânica.

2. Houve aumento significativo do teor de potássio trocável ( $2 \underline{a}$ amostragem) e de fósforo extraído ( $2 \underline{a}$ e $3 \mathfrak{a}$ amostragens) em função das diferentes seqüências culturais estudadas, porém, somente na profundidade de $0-20 \mathrm{~cm}$.

3. Houve aumento significativo do teor de magnésio trocável em função das diferentes seqüências culturais estudadas, nas amostragens de números 3 e 4 , nas profundida des de 0-20 e 20-40 cm. 
4. $\mathrm{O} \mathrm{pH}$ em $\mathrm{H}_{2} \mathrm{O}$, para as duas profundidades avaliadas, não apresentou diferenças significativas em relação às seqüências culturais estudadas. Para o pH em $\mathrm{CaCl}_{2}$, ocorreu diferença significativa, somente para a profundidade de 20-40 cm, na amostragem de número 2.

5. Após quatro anos de condução das diferentes seqüências culturais, constatou-se diferenças significativas no diâmetro médio ponderado dos agregados estáveis em água (D.M.P.), sendo os tratamentos T2, T4 e T3, os mais eficazes na agregação.

6. Não houve efeito das diferentes seqüencias culturais estudadas sobre a densidade e porosidade do solo, nas duas profundidades avaliadas. 


\section{REFERÊNCIAS BIBLIOGRÁFICAS}

ADAMS, N.G. \& BARNETT, A.P. The role of grass in Conservation rotations on red and yellow Podzolic soils. In: CONGRESSO INTERNACIONAL DE PASTAgem, 9o São Paulo. Anais São Paulo. Alarico, p. 577-81. 1965.

ALDERFER, R.B. \& MERKLE, F.G. Structural stability and permeability of native forest soils compared with cultivated areas of the same soil type. Soil Science Society of America Proceedings, Madison, 6:98-103. 1941.

ALEXANDROVA, L.N. On the composition of humus substances and the nature of organo-mineral colloids in soil. Vol. II $7^{\text {th }}$. Int. Congress of Soil Science. Madison. Wisconsin, USA, P. 74-81. 1980.

ALLISON, F.E. Soil organic matter and its role in crop production. Elsevier Scientific Publishing Company. 637 P. 1973 .

Allison, F.E. Organic carbon. In: BLACK, C.A., ed. Methods of Soil Analysis. American Society of Agronomy.Madison, pt. 1, cap. 30, p. 374-91. 1965. 
BALDISSERA, I.T, Condições físicas de um solo terra roxa estruturada distrófica na encosta basáltica do Rio Grande do Sul sob diferentes manejos. Porto Alegre. UfRGs, Faculdade de Agronomia. 1985. 89 p. (Tese de Mestrado).

BALLESTERO, S.D. Relações entre densidade e umidade na compactação e agregação. Efeitos na porosidade e na cultura de feijoeiro (Vigna erngericulata c.v. IPEAN-V-69). Piracicaba. 1985. 82 p. (Mestrado - Escola Superior de Agricultura "Luiz de Queiroz"/USP).

BARBER, S.A. The influence of alfafa, broumegrass, and corn on soil aggregation and crop yield. Soil Science Society of America Proceedings, Madison, 23: 258-9.1959. BAVER, L.R. The effect of organic matter on soil structure In: CONGRESSO LATINO-AMERICANO DE BIOLOGIA DO SOLO, 20, Santa Maria, 1868. Progressos em Biodinâmica e Produtidade do Solo. Universidade Federal de Santa Maria, RS. P. 191-202.

BAVER, L.D.; GARDNER, W.H.; GARDNER, W.R. Soil physics. 4. ed. New York. John Wiley \& Sons. 1972. 498 p.

BERTONI, J. \& LOMBARDI NETO, F. Conservação do Solo. São Paulo. Livroceres. 392 p. 1985. 
BoOSalis, M.G. \& COOK, G.G. Plant discases. In: NATIONAL CONSERvation tillage CONference. Ankeny. Proceedings. Soil Conservation American Society. P. 114-20. 1973.

BRADFIELD, R. Soil conservation from the viewpoint of soil physics. Journal America Society Agronomy. Madison, 29 (2): 85-92. 1973 .

BRADY, N.C. Natureza e propriedade dos solos. 5ed. Rio de Janeiro. Freitas Bastos. 647 p. 1979.

BRAGagNOLO, N. \& MIELNICZUK, J. Cobertura do solo por palha de trigo e seu relacionamento com a temperatura e umidade do solo. Revista Brasileira de Ciência do Soló. Campinas, 14: 369-374. 1990.

BRASIL. Ministério da Agricultura. Levantamento de īeconhecimento dos solos do Estado de São Paulo. Ministério da Agricultura. Serviço Nacional de Pesquisas Agronômicas. Comissão de Solos. 634 p. (Boletim Técnico, 12). 1960 .

BROUNING, G.M. \& MILAN, F.M. Effect of different types of organic materials and lime on soil aggregation. Soil Science Society of America Proceedings. Baltimore, 57: 91-106. 1944 . 
CAMARGO, A.P. de; E.S. FREIRE \& W.R. VENTURINI. 1962. Adubação da batata doce em São Paulo. Parte II - Efeito do calcário e de vários adubos. Bragantia, Campinas, 21(1): $325-339$.

CAMARGO, A.0. Compactação do solo e desenvolvimento de plantas. Campinas, Fundação Cargill, 1983. 44 p (mimeografado).

CARPENEDO, V. Qualidade e estabilidade de agregados de Latossolo Roxo submetido a diferentes manejos. 120 p. Tese (Mestrado Agronomia - Solos). Faculdade de Agronomia, UFRGS, Porto Alegre, 1985.

CARPENEDO, V. \& J. MIELNICZUK. Estado de agregação e qualidade de agregados de latossolos roxos, submetidos a diferentes sistemas de manejo. Revista Brasileira de Ciência do Solo. 14: 99-105. 1990.

CASSOL, E.A. Controle de erosão. Universidade Federal do Rio Grande do Sul. Porto Alegre. Polígrafo. 1984.

CERQUERIA, R.R. Agregação de um latossolo vermelho escuro em vários períodos de tempo em função da incorporação de palhas e da acidificação e calagem. Faculdade de Agronomia. UfRGS. $74 \mathrm{p}$. Porto Alegre. 1984. (Tese de Mestrado). 
89.

CINTRA, F.L.D. Caracterização do impedimento mecânico em Latossolos do Rio Grande do Sul. 89 p. Tese (Mestrado, Agron. Solos), Faculdade de Agronomia, UFRGS. Porto Alegre. 1980.

CINTRA, F.L.D.; J. MIELNICZUK \& I . SCOPEL. Caracterização do impedimento mecânico em um latossolo roxo do Rio Grande do Sul. Revista Brasileira de Ciência do Solo, Campinas, 7: 323-327. 1983 .

COSTA, M.P. Efeito da matéria orgânica em alguns atributos do solo. Escola Superior de Agricultura "Luiz de Queiroz"/USP. 137 p. Piracicaba. 1983. (Tese de Mestrado).

DALLA ROSA, A. Práticas mecânicas e culturais na recuperação de características físicas de solos degradados pelo cultivo no solo Santo Ângelo (Latossolo Roxo Distrófico). Faculdade de Agronomia, UFRGS. 138 p. Porto Alegre. 1981. (Tese de Mestrado).

DAY, P.R. Particle fracionation and particle size-analysis. In: BLACK, C.A. ed. Methods of Soil Analysis Physical and Mineralogical Properties, Including Statiscs of Measurement and Sampling. $1^{e d}$. American Society of Agronomy, Madison, P. 545-566. 1965. 
DERPSCH, R. Importância da cobertura do solo e do preparo conservacionista. In: SIMPósio de manejo e PLANTIO DI-

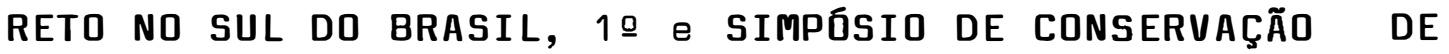
SOlos No Planalto, 3ㅁ, Passo Fundo. Anais... Passo Fundo, Faculdade de Agronomia/PIUCS, UFP. 1984.

DUCHAUFOR, P. Pédologie et classification. Paris, Masson, P. 27-63. 1978 .

DULEY, F.L. Surface factors affecting the rate of intake of water by soils. Soil Science Society of America Proceedings, Madison, 4:60-4. 1939.

ELLIOTT, L.F.; T.M. MC CALLA \& A. NAISS JUNIOR. Phytotoxity associeted with residue management. In: CROP RESI DUE MANAGEMENT SYMPOSIUM, Houston, 1976. Crop Residue Management Systems. Madison, ASA, CSSA, SSSA, P. 131-46. 1978 .

ELSON, J. \& J.F. LUTZ. Factors affecting aggregation of cecil soils and effect of aggregation on runoff and erosion. Soil Science. Baltimore, 50(3): 265-75. 1940.

FERNANDES, B.; H.M. GALLOWAY; R.D. BRONSON \& J.V. MANNERING. Efeito de três sistemas de preparo do solo na densidade aparente, na porosidade total e na distribuição dos poros, em dois solos (Typic Argiaquoil e Typic Hapludalf). Revista Brasileira de Ciência do Solo. Campinas, 7:329333. 1983. 
FORSYTHE, W. Física de Suelos: Manual de Laboratório. San José. IICA. 212 P. 1975.

GAVANDE, S.A. Física de Suelos; principios y aplicaciones. México, Limosa-Uiley. 351 p. 1973.

GHANI, M.O.; K.A. HASAN \& M.F.A. KHAN. Effect of lime on aggregation, noncapillary pore space, and permeability of lateritic soil. Soil Science. Baltimore, 80: 469478. 1955.

GROHMANN, F. \& H.V. ARRUDA. Influência do preparo do solo sobre a estrutura da terra roxa-legitima. Bragantia. Campinas, 20: 1203-209. 1961.

HARRIS, R.F.; G. CHESTERS; O.N. AlLEN \& O.J. ATtOE. Mechanisms involved in soil aggregate stabilization by fungi and bacteria. Soil Science America Proceeding. Madison. 28: $529-532$. 1964 .

HARRIS; R.F. ; G. CHESTERS \& O.N. ALLEN. Dymamics of soil aggregation. Advances in Agronomy. New York, 18: 107169. 1966.

HÉNIN, S.; R. GRAS \& G. MONIER. Os solos agrícolas. Rio de Janeiro. Editora Forense Universitária Ltda. 327 p. 1976.

JORGE, J.A. Solo, Manejo e Adubação. São Paulo. Ed. Nobel. 309 P. 1983. 
KEMPER, W.D. \& W.S. CHEPIL. Size distribution of aggregation. In: BLACK, C.A., ed. Methods of soil analysis. American Society of Agronomy, Madison, pt. 1. cap. 39 , p. 499-510. 1965 .

KIEHL, E.J. Manual de Edafologia: Relação Solo/Planta. São Paulo, Ceres. 263 p. 1979.

LAL, R. Role of Mulching Techniques in Tropical Soil and Water Management. Ibadan. International Institute of Tropical Agriculture. 37 p. (Technical Bulletin, 1). 1974 .

LAL, R. Modification of soil fertility characteristics by management of soil physical properties. In: GRENLAND,D. J. ed. Soil physical properties and crop production in the tropics. New York, J. Wiley, cap. 7, p. 397- 405. 1979 .

LASSUS, C. Composição dos resíduos vegetais em um solo manejado com nove sistemas de culturas. Revista Brasileira de Ciência do Solo, Campinas, 14: 375-380. 1990.

MACHADO, J.A. Efeito dos sistemas de cultivo reduzido e convencional na alteração de algumas propriedades físicas e químicas do solo. 129 p. Centro de Ciências Rurais, UfSM. Santa Maria. 1976. (Tese de Mestrado). 
MANNERING, J.V.; JONSON;-LC.; MEYER, L.D.\& JONES; B.A. The erosion-control effectiveness of rotation meadows. Journal of Soil and Water Conservation. Ankeny, 19(3): 9195. 1964 .

MARTIN, J.P. \& WASKMAN, S:A. Influence of microorganisms on soil aggregation and erosion. Soil Science. Balti more, 50: 29-47. 1940.

MARTIN, J.P. \& WAKSMAN, S.A. Influence of microorganisms on soil aggregation and erosion. II. Soil Science. Baltimore. 52(5): 381-394. 1941.

MASCARENHAS, H.A.A.; MIYASAKA, S.; LOVADINI, L.A.C.; FREIRE, E.S.; TEOFILO SOBRo, J.; CRUZ, L.P.; NERY, C. \& ANDRADE de F.C. 1967. Efeito da adubação verde do feijoeiro "da seca" com Crotalaria juncea L., empregando-se toda a vegetação ou retirando-se do campo as hastes despojadas de suas folhas. Bragantia, Campinas, 26: 219-234.

MEDEIROS, J.C. Sistemas de culturas adaptadas à produtividade, recuperação e conservação do solo. Porto Alegre. Faculdade de Agronomia. UFRGS. 89 P. 1985. (Tese de Mestrado). 
MELLO, F.A.F. de \& BRASIL SOBRINHO, M.O.C. do. Efeitos da incorporação de resíduos de mucuna, C. juncea e feijão baiano. II. Influência sobre o teor de cálcio trocável do solo. III. Relação cálcio trocável x produção de arroz. Revista de Agricultura, Piracicaba. 35(4): 249255. 1960 .

MINHONI, M.T.A,; EIRA, A.F. \& CARDOSO, E.J.B.N. Efeitos da adição de $N$ e $P$ sobre a decomposição de diferentes tipos de material orgânico no solo. Revista Brasileira de Ciência do Solo. Campinas, 14: 297-304. 1990.

MUSICK, G.J. \& BEASLEY, L.E. Effect of the crop residue system on pest problems in field corn (Zea mays) production. In: CROP RESIDUE MANAGEMENT. Symposium, Houston, 1976. Crop residue management systems. Madison, ASA, CSSA, SSSA, P. 173-86. 1979.

OLIVEIRA, J.B. \& SILVA, J.R.C. Efeitos do manejo do solo na erosão do podzólico vermelho amarelo-equivalente eutrófico e planossolo solódico da microrregião homogênea 68 do Ceará. Revista Brasileira de Ciência do Solo. Campinas, 6: 231-235. 1982.

OLIVEIRA, M. de; CURI, N. \& FREIRE, J.C. Influência do cultivo na agregação de um podzólico vermelho amarelo-textura média argilosa da região de Lavras (MG). Revista Brasileira de Ciência do Solo. Campinas, 7: 317-322.1983. 
RAIJ, B. van \& QUAGGIO, J.A. Métodos de análises de solos para fins de fertilidade. (Boletim Técnico, 81). Instituto Agronômico, Campinas. 1985.

RESCK, D.V.S. \& PEREIRA, J. 1979. Efeito da incorporação de restos culturais e adubo verde nas propriedades físicas de um Latossolo Vermelho Amarelo fase cerrado. In: 17ọ Congresso Brasileiro de Ciência do Solo. Manaus. p. 1. (Resumos).

ROTH, C.H.; PAVAN, M.A.; CHAVES, J.C.D.; MEYER,B. \& FREIRE, H.G. Efeitos das aplicações de calcário e gesso sobre a estabilidade de agregados e infiltração de água em um latossolo roxo cultivado com cafeeiros. Revista Brasi leira de Ciência do Solo. Campinas. 10: 163-166. 1986.

RUSSEL, E.W. Soil conditions and plant growth. 10 ed. New York. Longman. P. 397-420. 1973.

SCHEFFER, F. \& SCHACHTSCHABEL, P. Lehrbuch der bodenkunde. Ferdinand Enke Vulag. Stuttgart. Germany. 1979.

SETZER, J. Contribuição para o estudo do clima do Estado de São Paulo. São Paulo. Escolas Profissionais Salesia nas, P. (1)-239. 1946 .

SHIH-CHUNG, W. \& CHIN-CHEN. 1970. Effects of green manu ring in the cabe fields of Taiwan. Taiwan Sugar. Tainan. $17(3): 2-13$ 
SILVA, I.F. Efeito de sistemas de manejo e tempo de cultivo sobre as propriedades físicas de um latossolo. Faculdade de Agronomia. UfRgs. Porto Alegre. 1980. (Tese de Mestrado).

SKERMAN, P.J. Tropical forage legumes. Roma. FAO, cap. 1 p. 1-9. 1977 .

TEDESCO, M.J.; VOLKLEISS, S.J. \& BOHNEN, H. Análise de solo, planta e outros materiais. Porto Alegre, RS. Faculdade de Agronomia. UfRgs. 1985. (Boletim Técnico,5).

UHLAND, R.E. Physical properties of soil as modified by crops and management. Soil Science Society of America Proceedings, Madison, 14: 361-6. 1949.

VAN BAVEL, C.H.M. Mean Weight - Diameter of Soil Aggregates as a Statistical Index of Aggregation. Soil Science Society of America Proceedings. Madison, 38(6): 946950. 1949 .

VIDOR, C. O manejo do solo e a população de organismos. In: Simpósio de manejo do SOLO E PLANTIO diRETO NO SUL do BRASIL, 10 e SIMPósio dE CONSERVAÇÃO DE SOLOS DO PLANALT0, 30, Passo Fundo. 1984. Anais... Passo Fundo, Faculdade de Agronomia/PIUCS, UPF. 1984. 
VIEGAS, G.P.; GARGANTI, \& FREIRE, E.S. Efeito da mucuna do calcário e de outros adubos sobre as propriedades químicas do solo. Bragantia. Campinas, 19(1): 91-100.

VITTI, G.C.; FERREIRA, M.E.; PERECIN, D. \& ZANETTI NeTO. 1979. Influência de cinco leguminosas, como adubação verde na fertilidade de um Latossolo Vermelho :Amarelo fase arenosa (LVa). Científica. Jabotical, 7(3): 431435.

WATSON, J.H. \& STOJANOVIC, B.J. Sythesis and bonding of soil aggregated as effected by microflora and its meta bolic products. Soil Science, Baltimore,100:57-62. 1965.

WUTKE, A.C.P. \& ALVAREZ, R. 1968. Restauração do solo para a cultura da cana-de-açúcar. III. Período 1958-61. Bragantia. Campinas, 27(1): 201-217. 